Meri Kunčić: Tko je važan, a tko nije? O razlozima uvrštenja dvaju uglednih rapskih renesansnih kanonika u integralni abecedarij Hrvatskoga biografskoga leksikona

\title{
Tko je važan, a tko nije? O razlozima uvrštenja dvaju uglednih rapskih renesansnih kanonika u integralni abecedarij Hrvatskoga biografskoga leksikona
}

\author{
Meri Kunčić ${ }^{\oplus}$ \\ Leksikografski zavod Miroslav Krleža, Zagreb \\ meri.kuncic@1zmk.hr
}

SAŽETAK: U radu se, na temelju izvorne građe, nastoji proniknuti u životni put i djelatnost dvaju protagonista rapskoga društvenoga i kulturnoga života u drugoj polovici XV. st. U to je vrijeme, naime, u rapskoj komuni živjelo više kanonika koji su obnašali važne crkvene i javne dužnosti te uvelike kreirali svakodnevicu sredine u kojoj su živjeli. Među njima bili su i Toma Stančić, dugogodišnji rapski notar, prokurator katedralne crkve sv. Marije, te Toma Zangarel, dugogodišnji prior crkve sv. Katarine na Komrčaru. Svaki od njih dao je poticaj uređenju crkvenih i karitativnih ustanova na Rabu kojih su bili priori i prokuratori. Analiza ujedno otkriva da je kanonik i notar Toma Stančić znatno pridonio vjerskoj kulturi Raba svojim prijepisom Historia sancti Christophori Martyris te kao promicatelj, zajedno s rapskim patricijem Petrom de Zaro, novoga vjerskoga kulta Tijela Kristova. Njegov suvremenik Toma Zangarel, dugogodišnji prior crkve sv. Katarine na Komrčaru, bio je poduzetna osoba koja je poslovala s različitim slojevima rapskoga društva. Nekoliko njegovih oporuka (zapisanih u rasponu od 1452. do 1478) govori o njegovu obiteljskom krugu, bliskim mu suradnicima i skrbi o crkvenim i karitativnim ustanovama na Rabu. U drugom dijelu analize raspravlja se o kriterijima po kojim bi ta dva pojedinca mogla biti uvrštena u jednu od temeljnih edicija Leksikografskoga zavoda Miroslav Krleža, Hrvatski biografski leksikon.

Ključne riječi: Rab; kasni srednji vijek; kulturna povijest; Toma Stančić; Toma Zangarel; Hrvatski biografski leksikon

\section{Uvod}

Prva desetljeća XXI. st. u hrvatskoj medievistici obilježena su velikim tematskim pomacima u istraživanju prošlosti, zahvaljujući sve snažnijoj uklopljenosti hrvatske medievistike u suvremene internacionalne historiografske znanstvene tokove. Prihvaćanjem inovativnih metodologija stranih medievista, ali i novim i originalnim metodološkim pristupima hrvatskih povjesničara s obzirom na specifične izvore i probleme hrvatskoga srednjovjekovlja, postignuti su vrijedni znanstveni rezultati,

(D) https://orcid.org/0000-0002-9695-2502 [Meri Kunčić] 
osobito na područjima donedavno slabo razmatranih ili potpuno zapostavljenih tema kao što su hagiografska, migracijska, religiozna, ekološka, svakodnevna, urbana i povijest emocija, ali i na područjima tradicionalne historiografije (politička i ekonomska povijest). S obzirom na tu činjenicu, u ovom radu razmotrit će se pitanje utjecaja suvremene hrvatske medievistike na hrvatsku leksikografiju, odnosno na nužnost razrade novih kriterija koji bi mogli utjecati na izbor osoba i obitelji koje zaslužuju biti zastupljene u Hrvatskom biografskom leksikonu.

Naravno, ovaj vrlo kompleksan problem nije moguće u cijelosti razmotriti u ovom radu pa će se na neke aspekte suodnosa suvremene medievistike i leksikografije nastojati ukazati na jednom primjeru. Razdoblje koje će biti razmotreno je kasni srednji vijek, prostor analize je urbani dio rapske komune (civitas Arbe), a osnovna je tema rapska urbana elita. Ovo tematsko i prostorno-vremensko određenje prije svega je uvjetovano sačuvanošću obimnih fondova bilježničke građe u vrijeme kada je ustanova rapskoga bilježništva prolazila kroz tzv. proces demokratizacije, što znači da su postavljeni temelji pravnom i administrativnom omogućivanju bilježenja privatno-pravnih isprava $i$, što je osobito važno, da su pravne i administrativne odredbe vezane uz korištenje usluga komunalnih notara prihvaćene od muških i ženskih pripadnika svih gradskih staleža, ali i da se praksa bilježenja privatno-pravnih isprava (oporuka, inventara, kupoprodajnih ugovora, darovnica, ugovora o prokuraturi, o mirazu, o davanju zemlje u najam i dr.) kod notara proširila i na seosko stanovništvo u komunalnom distriktu. ${ }^{1}$

Učestalost zastupljenosti istaknutih pojedinaca, pripadnika rapske urbane svjetovne i duhovne elite, $u$ bilježničkim ispravama ponajbolje ilustrira dinamiku društvenoga života određenih pojedinaca u javnim, političkim, gospodarskim, crkvenim ili intelektualnim sferama. Upravo je otkrivanje takvih pojedinaca, kroz proučavanje objelodanjenoga ili neobjavljenoga arhivskoga gradiva i recentne znanstvene literature, osoba koje su promaknule prošlim sastavljačima abecedarija, a koji po određenim leksikografskim kriterijima zaslužuju biti zastupljeni u Hrvatskom biografskom leksikonu, jedan od važnijih zadataka suvremenih leksikografa.

U ovom radu, na temelju literature i analize neobjelodanjenih rapskih bilježničkih fondova, bit će predstavljena dva takva pojedinca, pripadnici rapske društvene elite i kreatori promicanja više novina vezanih uz društveni, kulturni, religijski, umjetnički i intelektualni život kasnosrednjovjekovnih Rabljana. Radi se s jedne

1 Za proučavanje prošlosti rapske komune iznimno je važan fond Bilježnici Raba koji se čuva u Državnom arhivu u Zadru pod signaturom HR-DAZD-28. Više o sadržaju toga fonda vidjeti u: Stjepan Antoljak: Izvori i literatura o prošlosti otoka Raba od ranog srednjeg vijeka do godine 1797. Filozofski fakultet Zadar/Skupština općine Rab, Zadar-Rab 1986; Ivan Pederin: Fond rapskih knezova i bilježnika. Vjesnik Historijskih arhiva u Rijeci i Pazinu (dalje: Fond rapskih knezova i bilježnika), 25, 1982., str. 9-43. Opći podatci o sadržaju fonda nalaze se i na web stranici https://vodic.dazd.hr/dazd-0028/ (pristupljeno 24. II. 2021). 
strane o dugogodišnjem rapskom kanoniku i komunalnom javnom notaru Tomi Stančiću (Thomas de Stantiis), prioru hospitala i oltara Tijela Kristova i prokuratora katedrale sv. Marije u gradu Rabu, koji se vezuje uz niz dokumenata povezanih s rapskim biskupom Ivanom de Scaffa kao i patricijem Petrom de Zaro, te o drugom rapskom kanoniku Tomi Zangarelu (Thomas de Zanzarellis; de Çancarella; de Çanegrellis), koji je djelovao istovremeno te bio dugogodišnji prior crkve sv. Katarine na Komrčaru. Obojica su bili značajni protagonisti rapske svakodnevice druge polovice XV. st. Uz prikaz njihova života i djelovanja, u radu će se uputiti na leksikografske kriterije koji govore u prilog njihovu uvrštenju u spomenutu ediciju.

\section{Nesuglasje literature i izvora}

U dosadašnjoj znanstvenoj literaturi osobe iz rapskoga kulturnoga života druge polovice XV. st. sporadično su obrađene u različitim studijama, u cjelini gledano postojeće sinteze i pojedinačne studije toga razdoblja daju često nepotpune i kontradiktorne podatke, što upućuje na nužnost vraćanja izvorima i ponovno preispitivanje postojećih zaključaka. ${ }^{2}$ Budući da je u ovom radu riječ o dvjema osobama koje su imale važnu ulogu u kreiranju rapske svakodnevice tijekom gotovo pedesetak godina XV. st. (od konca 1430-ih do konca 1480-ih), ključno je bilo, zbog činjenice da su obojica bili rapski kanonici i imali isto ime (ali ne i prezime), točno ih identificirati u rapskim vrelima. Taj je zadatak uvelike otežan činjenicom da je jedan od njih redovito u izvorima zapisivan imenom i prezimenom te ulogom javnoga notara i kancelara rapske biskupije (Toma Stančić), a drugi češće samo imenom (Toma), rjeđe imenom i prezimenom (Toma Zangarel), i dužnošću priora crkve sv. Katarine na Komrčaru (presbiter Thomas, prior ecclesie sancte Catharine de Caminzario ac canonicus Arbensis). Zapravo je poznata tek nekolicina dokumenta zabilježenih u literaturi ${ }^{3}$

2 Primjerice, zabunu u istraživanju života i djelatnosti unosi podatak o postojanju dvojice suvremenih istoimenih kanonika u studiji I. Pederina, koji pritom razlikuje Tomu Stančića, kanonika i notara, i Tomu Stančića, kanonika i priora crkve sv. Katarine na Komrčaru. U tom smislu autor, oslanjajući se na bilježnički zapis Tome Stančića, piše sljedeće: »Rapski kaptol imao je 1474. slijedeći sastav: arciđakon je bio Juraj Marinellis, ali on je boravio u Rimu. Natpop je bio Martin Cernota, primicerij i vikar Mate Martinis. Kanonici su bili Julijan Šota, Toma Stančić, inače i bilježnik i drugi kanonik, koji se također zvao Toma Stančić, a bio je prior sv. Katarine...« Ivan Pederin: Svakidašnjica u Rabu: od mistike do renesanse i baroka (dalje: Svakidašnjica u Rabu). Matica hrvatska, Rab 2011, str. 32. Međutim, pažljiviji uvid u rapske izvore svjetovne i crkvene provenijencije upućuje na to da je zapravo riječ o dvije različite osobe, različita imena. Upravo je glavna namjera ovoga rada jasno razgraničiti njihovu djelatnost te ih postaviti u kontekst rapske kulture kasnog srednjovjekovlja. Na sugestijama i ustupljenim izvorima koji su olakšali identifikacije dvaju suvremenih kanonika zahvaljujem kolegicama dr. sc. Saši Potočnjak s Filozofskoga fakulteta u Rijeci i dr. sc. Zrinki Novak iz Odsjeka za povijesne znanosti Zavoda za povijesne i društvene znanosti HAZU u Zagrebu.

3 P. Runje spominje ga, primjerice, na sljedeći način: »Thomas Zangarel, svećenik i prior sv. Katarine na Komrčaru, 12. rujna 1451. prodao je više komada sitnoga blaga za 25 zlatnih dukata Mateju 
i sekundarnim izvorima, u kojima se spominje istovremeno i imenom i prezimenom te ulogom priora sv. Katarine na Komrčaru; najraniji takav spomen potječe iz 1439., ${ }^{4}$ a najkasniji iz $1478 .{ }^{5}$ po čemu bi se dalo zaključiti da je taj rapski kanonik dužnost priora priorata sv. Katarine na Komrčaru obnašao više od četrdeset godina.

Dva su ključna dokumenta koji omogućuju identifikaciju tih dviju osoba u rapskim vrelima, jedan je crkvene, a drugi svjetovne provenijencije. Prvi se nalazi u knjizi legata Rapske biskupije iz $1472 .{ }^{6}$ a drugi se odnosi na notarski zapis koji je zabilježio upravo Toma Stančić u svojoj bilježničkoj kancelariji $1474 .{ }^{7}$ U ranijem dokumentu donesen je popis beneficija Rapske biskupije iz 1472., odnosno popis prihoda pojedinih samostana, katedralne crkve te pojedinih kapela, crkava i priorata na području Rapske biskupije. Isti dokument donosi ujedno i popis osoba koje su upravljale pojedinim nadarbinama, među kojima su i imena dvojice kanonika o kojima je ovdje riječ, Tome Stančića i Tome Zangarela, ali bez naznake nadarbine kojom su upravljali. U nastavku, u popisu rapskih crkava i kapela nalazi se priorat sv. Katarine na Komrčaru koji se, kao što ćemo vidjeti iz kasnijega dokumenta, vezuje uz Tomu Zangarela. Iz istoga se popisa, međutim, ne može zaključiti kojom je nadarbinom, u godini nastanka dokumenta, upravljao kanonik i notar Toma Stančić. U kasnijem bilježničkom dokumentu, iz 1474. godine, navedena su ponovno oba kanonika s imenom Toma, od kojih je jedan Toma Stančić, a drugi Toma, prior sv. Katarine na Komrčaru.

S obzirom na to da je kanonik i notar Toma Stančić zapisao velik broj notarskih isprava, inventara rapskih crkvenih ustanova i različitih prijepisa, daleko se češće spominje u radovima autora koji su se bavili pojedinim temama rapske prošlosti. No, kao što će se nastojati pokazati u nastavku teksta, razloga za proučavanje njegova života i djelatnosti ima daleko više budući da je obnašao dužnost priora i prokuratora važnih crkvenih ustanova u rapskoj komini te sudjelovao u kreiranju humanističkoga ozračja koje je u sljedećoj generaciji, na prijelazu XV. i XVI. st., dalo neke od istaknutih predstavnika hrvatskoga humanizma. Drugi rapski kanonik o kojem je u ovoj studiji riječ, Toma Zangarel, daleko je manje zastupljen u literaturi, no vidjet ćemo da je, obnašajući dužnost priora priorata sv. Katarine na Komrčaru te kao glagoljaš blizak franjevačkoj trećoredačkoj zajednici na Rabu koji je promicao karita-

de Marmonea iz Raba. Usp. PAZ, Rapski arhiv, Kutija 1, str. 225v, 12. IX. 1451.« Petar Runje: Glagoljaši javni bilježnici (dalje: Glagoljaši). Senjski zbornik, 26, 1999, str. 116, bilj. 6.

4 Petar Runje: Franjevci trećoreci-glagoljaši na Rabu u srednjem vijeku (dalje: Franjevci trećoreci-glagoljaši). U: Rapski zbornik I (ur. Andre Mohorovičić). JAZU-Skupština općine Rab, Zagreb 1987, str. 333.

5 Odorik Badurina: Velika kamporska kronika. Liber II, str. 34.

6 ACA (Archiv. Capituli Arbi), Arhiv bivšega Rapskoga kaptola, Legata Ecclesiae Cathedralis, Liber 26 , fol. $54 \mathrm{v}$

7 DAZd, RB, TS, kut. 3, sv. XX, fol. 650r-v. 
tivnu djelatnost, uvelike utjecao na kreiranje svakodnevice komune u kojoj je živio. Među podatcima u bilježničkim dokumentima koji svjedoče o njegovoj djelatnosti osobito su vrijedne tri njegove sačuvane oporuke (iz $1452 .{ }^{8}, 1462 .{ }^{9}$ i $1478 .{ }^{10}$ ), koje govore o njegovom obiteljskom krugu i poslovnoj djelatnosti, kao i o skrbi za rapske vjerske i karitativne ustanove.

\section{Toma Stančić (Thomas de Stantiis), kanonik i notar, prokurator katedrale sv. Marije na Rabu}

Rođen je u obitelji Matije Stančića. Imao je brata, rapskoga građanina i krojačkoga majstora, Franju. ${ }^{11}$ Podrijetlom iz rapske pučke obitelji s pravom rapskoga civiteta, bio je zaštićen odredbama rapskoga komunalnoga statuta kao punopravni građanin. U rapskim bilježničkim spisima pojavljuje se vezano uz crkvene, ali i jednu svjetovnu službu. Kao rapski kanonik (canonicus Arbensis), u ispravama je zabilježen više puta tijekom svojega djelovanja, ${ }^{12}$ a kao javni bilježnik službovao je dugo, od $1444 .{ }^{13}$ do 1491. (publicus imperiali auctoritate notarius Arbensis). ${ }^{14}$ Bio je ujedno i dugogodišnji kancelar i službeni notar Rapske biskupije ${ }^{15}$ (dominus presbiter Thoma de Stantiis notarius

8 DAZd, RB, TS, kut. 2, sv. VI, fol. 55a-56.

9 DAZd, RB, TS, kut. 3, sv. XI, fol. 165r-165v.

10 Odorik Badurina: Velika kamporska kronika. Liber II, str. 34.

11 Franjo se povremeno također spominje u bilježničkim ispravama. Tako se, primjerice, spominje u srpnju 1454. kao magister Franciscus de Stanzo sartor u funkciji jednoga od svjedoka pri bilježenju oporuke Fume, udovice pok. Sentula de Bazocha nobilis domine Arbi (DAZd, RB, TS, kut. 2, sv. VI, fol. 73a), zatim u oporuci rapskoga patricija Petra de Zaro datiranoj 27. siječnja 1462 (DAZd, RB, TS, kut. 2, sv. XI, fol. 159r) kao i u listopadu 1473. u ugovoru o prodaji zemlje, kao majstor krojač Franjo de Stanciis frater Thomae notarii et presbiteri (DAZd, RB, AF, kut. 1, sv. IX, fol. 16a).

12 Daniele Farlati: Illyricum sacrum (dalje: Illyricum sacrum, sv. 5), 5. Venetiis, apud Sebastianum Coleti, 1775, str. 257, 260.

13 dominus presbiter Thoma de Stantiis canonicus Arbensis et notarius publicus. ACA (Archiv. Capituli Arbi), Arhiv bivšega Rapskoga kaptola, Documenta dioc. Arbensis, Liber 43, fol. 48 (1444)

14 U opisu fonda u Državnom arhivu u Zadru zapisano je njegovo ime s godinama obavljanja notarske službe (koje se ne poklapaju u potpunosti sa stvarnim rasponom njegova djelovanja kao javnoga notara), oznakama kutija i svežnjeva: Thoma de Stantiis q. Mathei 1448-1491, kut. 2-3, sv. I-XIX. HRDAZD-28; Dušan Mlacović: Građani plemići: pad i uspon rapskog plemstva (dalje: Građani plemići). Leykam inernational, Zagreb 2008, str. 317. Vjerojatno je da su ga za komunalnoga rapskog bilježnika postavili članovi obitelji de Nimira ili de Dominis, a koji su stekli privilegij postavljanja notara carskom ovlašću cara i kralja Žigmunda. Više o tome vidjeti u: Miroslav Granić: Privilegij cara Sigismunda rapskoj obitelji Dominis iz godine 1437. Radovi Filozofskog fakulteta u Zadru (dalje: Privilegij cara Sigismunda), 20(1980-81) 9, str. 53-62; I. Pederin: Fond rapskih knezova i bilježnika, str. 9-43.

15 Na dužnosti javnoga notara koji je službeno zapisivao i isprave Rapske biskupije još se u srpnju 1444. spominje Dominik de Plangos. ACA, Documenta dioc. Arbensis, Liber 43. fol. 169. (dok. datiran 27. VII. 1444) 
et curiae episcopalis cancellarius). ${ }^{16} \mathrm{Na}$ sličan se način spominje u nizu isprava od sredine 1440-ih do konca 1470-ih, ${ }^{17}$ primjerice u dokumentu iz razdoblja uprave rapskoga biskupa Leonellusa (Lionelus de Clericatus, 1472-1483/84), kada je 1476. zabilježen kao notar i kancelar Rapske biskupije zajedno s patricijem, arhiđakonom Rapskoga kaptola i rapskim notarom Antonom de Nimira. ${ }^{18}$ Po svemu sudeći, istodobno je djelovao i kao službeni prevoditelj isprava s hrvatskoga na latinski, no riječ je o segmentu Tomine djelatnosti koji još uvijek nije dovoljno istražen. ${ }^{19}$

Ujedno je zabilježen kao prokurator rapskoga biskupa. Na taj se način, primjerice, spominje u dokumentu iz 1446., u kojem se zajedno s Marinom de Nimira po-

16 Tako je zabilježen u dokumentu datiranom 9.12.1446. ACA, Documenta dioc. Arbensis, Liber 43. (bez navoda broja folije)

17 Ibid., dominus presbiter Thoma de Stantiis canonicus Arbensis et notarius publicus. fol. 48 (1444); dominus presbiter Thoma notarius. fol. 57 (1444); presbiter Thoma notarius. fol. 59 (1445); dominus presbiter Thoma de Stantiis notarius. fol. 337 (1446); dominus presbiter Thoma de Stantiis canonicus Arbensis ac cancellarius curiae episcopalis. fol. 43-44 (1447); dominus presbiter Thoma de Stantiis notarius publicus. fol. 75-75' (1448); dominus presbiter Thoma de Stantiis notarius. fol. 79 (1448); venerabilis dominus presbiter Thoma de Stantiis canonicus Arbensis notarius publicus et curiae episcopalis cancellarius. fol. 289 (1458); venerabilis dominus presbiter Thoma de Stantiis canonicus Arbensis notarius publicus et curiae episcopalis cancellarius. fol. 330 (1458); dominus presbiter Thoma de Stantiis notarius et cancellarius. fol. 46 (1460); dominus presbiter Thoma Stantiis. fol. 356 (1479).

18 Tako se u dokumentu iz 1476. spominje na sljedeći način: Ego Antonius Nimireus Arben. Archidiaconus Apostolica auctoritate Comes palatinus, et Imperiali notarius publicus, ac Fudex ordinarius, ex copia......Notarii posita in actis Ecclesisasticis Dom. Presbyteri Thoma de Stantiis Canonici Arben. Notarii, et curia episcopalis Cancellarii fideliter accopiavi. D. Farlati: Illyricum sacrum, sv. 5, str. 257.

19 U tom smislu P. Runje, interpretirajući rapska vrela, zaključuje sljedeće: „Samo se za neke svećenike glagoljaše navodi da znaju hrvatski. Ako se za druge ne spominje izričito da su vješti u hrvatskom jeziku, to ne znači da ga nisu poznavali. Čini mi se da imamo razloga vjerovati da su svi javni bilježnici, imenovani na Rabu, prije imenovanja bili poznavaoci latinskoga, što je bio uvjet za imenovanje javnim bilježnikom. Dio njih znao je i hrvatski i glagoljicu. To im je bio materinski jezik, kojim su se služili čak u dvije dosta različite varijante, tj. u redakciji staroslavenskoga jezika u crkvi i živoga narodnoga jezika u svagdanjoj govornoj živoj riječi. Thomas de Stantiis, svećenik i rapski javni bilježnik, pisao je latinski, koliko nam je poznato, sve svoje javne bilježničke spise. Ali poznavao je i hrvatski jezik, s kojeg je prevodio na latinski službene spise. 3. travnja 1459. preveo je s hrvatskoga na latinski oporuku pok. svećenika Petra iz Karlobaga, koju je pokojni Petar napisao 4. srpnja 1456. u Karlobagu« (uz tekst je vezana bilj. 27 u kojoj se autor poziva na Veliku kamporsku kroniku. Liber II, str. 843. (op. a. Liber I ), u kojoj stoji: »Rapski notar don Toma de Stantiis prenosi 'de uno folio sclavonico in latinum' testamenat svećenika Petrice in Scrixia, učinjen u Scrisiji (Bagu) 1456. 4. VII.« U istoj bilješci nadalje se navodi: Godine 1472. piše pismo na hrvatskom Pavao Zachej, svećenik i kapelan u Novalji i želi da ga na latinski službeno prevede Thomas de Stantiis, javni bilježnik u Rabu. Usp. PAZ, Rapski arhiv, Kutija 1, str. 121 r-v). P. Runje: »Glagoljaši javni bilježnici«, u: Senjski zbornik, 26, 1999, str. 119. Runjina je pretpostavka vjerojatno točna, što potvrđuje primjerice činjenica da je službu javnoga bilježnika u Karlobagu te kancelara senjskoga biskupa obnašao Rabljanin Marin Maroman koji je zapisivao privatno-pravne isprave na hrvatskoj glagoljici u isto vrijeme dok je bio i rapski bilježnik sastavljajući isprave na latinskom. U jednoj ispravi sastavljenoj u Jablancu (Karlobagu) u travnju 1485. on se potpisao kao »Marin'čul Maroman’ z Raba, notar publik' i tada kan'celir g(ospo)d(i)na bis'kupa senjs'koga prošen' pisah«. Vidi: Josip Bratulić: Hrvatske glagoljične i ćirilične isprave iz zbirke Stjepana Ivšića 1100.-1527., Acta Croatica. Hrvatski spomenici, knj. 1. Isprave, HAZU, Zagreb 2017, dok. 104, str. 241. 
javljuje u ulozi prokuratora, pri čem je Marin prokurator cijeloga Rapskoga kaptola, a prezbiter Toma prokurator rapskoga biskupa. ${ }^{20}$ Tim se ugovorom, kojim se dogovaraju obveze plaćanja godišnjega doprinosa ${ }^{21}$ samostana sv. Stjepan u Barbatu rapskome biskupu i Kaptolu, postiže njihov dogovor s prokuratorom samostana Nikolom de Scaffa. Pritom se u istom dokumentu kao jedan od svjedoka spominje i Toma, prior crkve sv. Katarine na Komrčaru. ${ }^{22}$

Vidno je da se trajna svećenička služba Tome Stančića nije kosila s obavljanjem svjetovne javnobilježničke prakse, pa je tako istodobno bio notarius publicus Arbensis i kanonik Rapskoga kaptola. Svoje je prvo obrazovanje vjerojatno stekao kod lektora Rapskoga kaptola, gdje se upoznao i s osnovama kanonskoga i rimskoga prava. Školovanje za svjetovnoga bilježnika nastavio je potom zasigurno u nekoj od rapskih bilježničkih škola, gdje se upoznao s odredbama rapskoga statuta, s pravilima pisanja privatno-pravnih dokumenata bilježničkoga karaktera te s građanskim pravom utemeljenom na rimskom pravu. ${ }^{23} \mathrm{Je}$ li se školovao na sveučilištima u Bologni ili Padovi, ostaje zasad nepoznato. ${ }^{24}$ Bilježničke isprave zapisivao je latinicom i latinskim jezikom. Njegova pojava unutar kruga rapskih notara svjedoči o sve učestalijem djelovanju notara domaćega, rapskoga podrijetla, kao što su njegovi suvremenici Andrija Fajeta i Marin Maroman, koji su bili jednako profesionalni kao i bilježnici pridošli s Apeninskoga poluotoka. ${ }^{25}$ Tijekom svoje dugogodišnje bilježničke službe zapisao je velik broj različitih isprava, poslovnih ugovora, ugovora o prokuraturi,

20 D. Farlati: Illyricum sacrum, sv. 5, str. 253; ACA, Documenta dioc. Arbensis, Liber 43. (bez navoda broja folije, datacija 9.12.1446)

${ }^{21}$ Samostan je pritom obvezan plaćati biskupu i Kaptolu godišnji regalia i decim u iznosu 3 libre i 4 solida. Ibid.

22 ACA, Documenta dioc. Arbensis, Liber 43. (bez navoda broja folije, datacija 9. 12. 1446)

23 O školovanju kanonika bilježnika vidjeti više u: Ante Gulin: Hrvatski srednjovjekovni kaptoliLoca credibilia Dalmacije, Hrvatskog primorja, Kvarnerskih otoka i Istre. HAZU, Zagreb 2008, str. 16, 334.

24 Ipak, treba reći da su bilježničke vještine obično zahtijevale poznavanje pravila sastavljanja raznih vrsta privatno-pravnih isprava, osobito s obzirom na poznavanje rimskoga i kanonskoga prava $i$ specifičnih bilježničkih pravnih formula koje su korištene u raznim vrstama isprava. Zbog toga je velik broj dalmatinskih studenata, a među njima i kanonika, primjerice iz Dubrovnika, studirao na sveučilištima u Padovi i Bologni kako bi stekli sveučilišnu bilježničku naobrazbu. I neki od bilježnika koji su pisali glagoljicom, osobito oni s prostora današnjega Kvarnera, pored naobrazbe stečene u kaptolskim školama, a poznati kao scribe, imali su sveučilišno obrazovanje. No, za Tomu Stančića nemamo takve podatke. Vidi: Nella Lonza: Dubrovački studenti prava u kasnom srednjem vijeku, Anali Zavoda za povijesne znanosti HAZU u Dubrovniku, 48 (2010), str. 9-45.

25 Razvoj notarijata na Rabu do sada nije sustavno obrađen, pojedini segmenti te problematike obrađeni su u radovima: M. Granić: Privilegij cara Sigismunda, str. 53-62; Dušan Mlacović: Supetarska Draga na Rabu v srednjem veku. U: Raukarov zbornik. Zbornik u čast Tomislava Raukara (ur. Neven Budak), Filozofski fakultet Sveučilišta u Zagrebu-Odsjek za povijest, Zagreb 2005, str. 513-535; Lujo Margetić: Iz starije pravne povijesti Raba, u: Lujo Margetić i Petar Strčić: Statut rapske komune iz 14. stoljeća. Grad Rab /Adamić/, Rab-Rijeka 2004, str. 21-75. 
ugovora o mirazu, ugovora o nauku odnosno šegrtovanju, kupoprodajnih ugovora, ugovora o najmu, kupnji ili prodaji nekretnina (kuća, koliba ili zemljišnih posjeda razne vrste), oporuka i kodicila kao dopuna ili izmjena oporuka i druge privatno-pravne isprave.

Upravo je bilježnik i kanonik Toma zapisao i brojne ugovore koje su rapski patriciji, posebice od konca 1440-ih i tijekom 1450-ih, sklapali s majstorima graditeliima i kamenoklesarima, vezanim uz gradnju i uređenje pojedinih svjetovnih i sakralnih građevina. Ključna je u tom smislu bila, njegova u izvorima potvrđena i već spomenuta povezanost s uglednim rapskim patricijem Petrom de Zaro (Petar Car), patronom franjevačkoga samostana sv. Bernardina Sijenskoga na Rabu i utemeljiteljem pripadajuće mu samostanske crkve s istim titularom, čije je mnoge ugovore o gradnji i uređenju zapisao upravo Toma u svojoj bilježničkoj kancelariji. ${ }^{26}$ Jednako je tako zapisao i niz ugovora koje su rapski biskup Ivan de Scaffa i drugi rapski patriciji potpisali s uglednim majstorima pa tako i renesansnim majstorom Andrijom Alešijem, vezano uz gradnju i uređenje mnogih kapela u rapskim crkvama pa tako i u katedralnoj crkvi sv. Marije. ${ }^{27}$

Toma se spominje kao ispovjednik patricija Petra de Zaro već u njegovoj prvoj oporuci zapisanoj u listopadu 1450. godine. ${ }^{28}$ Kao svom ispovjedniku, Petar je Tomi darovao ducatos octo auri pro triginta vna missa sancti Gregorii et pro quadraginta missis za svoju dušu te pro meo labore (tj. za Tomin posao). ${ }^{29} \mathrm{U}$ kodicilu koji je Petar de Zaro zapisao 27. siječnja 1458., Toma je postavljen, odlukom samoga Petra, za priora hospitala Tijela Kristova smještenoga uz katedralu sv. Marije te za priora pripadajućega mu oltara smještenoga u katedrali (prior altaris Corporis Christi et hospitalis sui positi apud ecclesiam cathedralem). ${ }^{30}$ Time se, zajedno s patricijem Petrom, iskazao kao promicatelj tada popularnoga kulta Tijela Kristova izraženoga riječima caritas et misericordia i usmjerenoga prema siromašnima i bolesnima. ${ }^{31} \mathrm{U}$ oporuci Petra de

26 Cvito Fisković i Kruno Prijatelj: Albanski umjetnik Andrija Aleši u Splitu i Rabu (dalje: Albanski umjetnik Andrija Aleši). Izdanje Konzervatorskoga zavoda za Dalmaciju u Splitu, Split 1948, str. 2729, 42-43; O historijatu samostanskoga sklopa u Kamporu na Rabu i pripadajuće mu crkve sv. Bernardina više vidjeti u: Ivan Braut, Krasanka Majer Jurišić, Edita Šurina: Franjevački samostanski kompleks sv. Bernardina Sijenskog u Kamporu na otoku Rabu. Mala biblioteka Godišnjaka zaštite spomenika kulture Hrvatske, 21. Zagreb 2020.

27 Ibid.; Miroslav Montani: O radovima Jurja Dalmatinca i njegova kruga (dalje: O radovima Furja Dalmatinca). Ljetopis $\mathcal{F A Z U , ~ 7 0 , 1 9 6 5 , ~ s t r . ~ 4 5 5 - 4 8 1 , ~ o s o b i t o ~ s t r . ~ 4 6 4 - 4 7 1 . ~}$

28 DAZd, RB, TS, kut. 2, sv. IV, fol. $1168 \mathrm{v}-1169 \mathrm{v}$.

29 Ibid., 1169v. I ova neuobičajeno velika svota novca koju je Petar oporučno darovao Tomi »za njegov posao« upućuje na njihovo čvrsto prijateljstvo.

${ }^{30} \mathrm{DAZd}$, RB, TS, kut. 2, sv. VIII, fol. 122v-123v.

31 Više o vjerskom kultu Tijela Kristova u kasnosrednjovjekovnom Rabu vidjeti u: Meri Kunčić: Dalmatinski patricijat i socijalno kršćanstvo. O srednjovjekovnim rapskim hospitalima s posebnim 
Zaro iz siječnja 1462. notar i kanonik Toma Stančić naziva se svećenikom (prezbiter) i Petrovim ispovjednikom te je od ovoga testatora potvrđen za priora oltara Tijela Kristova za Petrova života ${ }^{32}$ te za priora hospitala corporis Christi. ${ }^{33} \mathrm{Na}$ dužnosti priora oltara Tijela Kristova bio je, kako svjedoče vrela, upraviteljem uistinu bogata priorata koji je obuhvaćao velik broj nepokretnih dobara u gradu Rabu i na području rapskoga distrikta. ${ }^{34}$

Uloga Tome kao priora bila je iznimno važna u crkvenom i društvenom životu jer je tom funkcijom bio zadužen za održavanje nekretnina koje su spomenuti hospital i oltar dobivali kao oporučne legate, ali i za dobiveni novac te vrijedne liturgijske predmete. Općenito su priori bili osobe s poznavanjem prava koje su štitile i brinule se o prihodima i rashodima civilnih ustanova kao što su hospitali i bratovštine ili crkvenih ustanova kao što su crkve, kapele pa i oltari. ${ }^{35} \mathrm{Nad}$ njime su stajali kontrolni sustavi - bilo Crkva bilo istaknuti članovi bratovština (gastaldi) ili dužnos-

osvrtom na hospital Tijela Kristova i njegova utemeljitelja Petra de Zaro. Croatica Christiana periodica, 4(2016) 77, str. 25-76. Od prve polovice XV. st. dolazi do procvata kulta Tijela Kristova u cijeloj Europi pa tako i u pojedinim komunama na istočnoj obali Jadrana. Veliki promicatelj kulta Tijela Kristova bio je papa Eugen IV (1431-47) čija je kancelarija 1433. izdala bulu kojom se objavljuje slavljenje toga kulta i davanje oprosta svima onima koji na taj blagdan posjete Rim i sudjeluju u blagdanskim svečanostima, ali i svima onima koji u svojim mjestima slave blagdan Tijela Kristova. Za hrvatsku je povijest još važnije što je papa bulu vezanu uz slavljenje toga blagdana razaslao diljem Europe, a jedan primjerak i franjevačkom samostanu u Zadru, odnosno na područje Zadarske nadbiskupije, čiji je sufragan bila Rapska biskupija. Nema sumnje da je ta činjenica utjecala na prihvaćanje i snaženje kulta Tijela Kristova unutar Rapske biskupije. S obzirom na to da Arhiv samostana sv. Frane u Zadru nije uređen u skladu sa suvremenim arhivističkim načelima, bula se čuva pod nepotpunom signaturom: Arhiv samostana sv. Frane u Zadru, Zbirka isprava na pergameni, isprave br. 95-120, kut. XIV, br. 106. Popis spisa arhiva samostana sv. Frane u Zadru, napravio je Odorik Badurina. Iz njegova rukopisa pisanoga pisaćim strojem 1968., prijepis je 2017. izradio Stjepan Škunca.

32 ... ex nunc elegit me presbiterum Thomam, confessorem suum, in priorem sui altaris Corporis Christi in vita mea. DAZd, RB, TS, kut. 2, sv. XI, fol. 158v-159r.

33 Ibid.

34 Prioratus altaris Corporis Christi habet possessiones, terena et derum infrascriptum, videlicet vnam possessionem positam sub monte sancti Damiani...; unam suam possessionem positam in Slana...; terram aratoriam positam in Capirigno Patergulo; duas suas terras aratoriaas positas in Capirigno...; unam suam terram positam in Camoschaglio ...; unam suam terram aratoriam positam in Snua...; unam suam terram aratoriam positam ibidem quam confinat cum terris hospitalis sancti Nicolai; unam suam vineam positam in Barbato in Montignuso...;unum suum pastinum positum in Barbato...; unum suum derrum cum arboribus oliuarium positum in contrata sancti Marci ... pro oleo ponendo in Corporis Christi sex stariorum quin arbores fructabunt et pro hospitali suo cum suis onere et honore sicut continetur in testamento nobilis viri ser Petri de Zaro notato manu mei presbiteri Thome de Stanciis, notarii et prioris in 1462, indictione decima, die uero 27 mensis Ianuarii et cetera. ACA, Documenta dioc. Arbensis, Liber 43, fol. 158 (dokument datiran 27. 1. 1462)

35 Više o ulozi prokuratora i priora u djelovanju hospitala u komunama na istočnom Jadranu vidi u: Zoran Ladić: O šibenskim hospitalima i leprozorijima kasnog srednjeg vijeka prema bilježničkim spisima. U: Šibenik od prvog spomena (ur. Iva Kurelac). Muzej grada Šibenika, Šibenik 2018, str. 153-174, osobito str. 160-165. 
nici komunalnih vlasti. Povijesna vrela potvrđuju da nisu bile rijetke optužbe na račun priora (uglavnom pripadnika klera) da kao priori novac troše za vlastite potrebe. Međutim, Toma Stančić se u toj, kao uostalom i svim ostalim dužnostima koje je obnašao u rapskoj zajednici, po svemu sudeći ponašao vrlo savjesno i časno. $\mathrm{O}$ tome svjedoče gotovo sve isprave koje spominju Tomu Stančića kanonika i notara, ${ }^{36}$ kao i činjenica da je bio i jedan od izvršitelja u oporuci njegova suvremenika Tome Zangarela, također uglednoga pojedinca u rapskoj komuni. ${ }^{37}$

Nesumnjivo je Toma kao prvi prior oltara Tijela Kristova bio zadužen za nabavku liturgijske opreme, ali je prije svega trebao naručiti izradu oltara koji se zasigurno nalazio u zasebnoj kapeli, ${ }^{38}$ te dogovoriti njegovo umjetničko-liturgijsko uređenje. U tom se smislu može naslutiti Tomin najneposredniji doprinos prihvaćanju kasnosrednjovjekovne internacionalne gotičko-renesansne kulture, gdje je s prihvaćanjem vjerskih kultova i obrednih običaja vjerojatno prihvatio i određena umjetnička rješenja. Naime, u samoj su Veneciji toga doba zasebni oltari posvećeni Tijelu Kristovu bili rijetki jer se posvećena hostija uglavnom čuvala u posebnim, za to namijenjenim kamenim tabernakulima koji su bili smješteni obično na lijevom zidu uz glavni oltar. Među postojećim rijetkim primjerima zasebnih oltara posvećenih Tijelu Kristovu nalaze se uglavnom oni drveni, gotički oblikovani oltari ukrašeni skulpturom i slikama, dok su mramorni oltari s izrazitijom arhitektonskom strukturom, također ukrašeni skulpturom, na području Venecije postali učestaliji tek od XVI. st. ${ }^{39}$ Premda bilježnički ugovori daju tek šture podatke o tom segmentu interesa Petra de Zaro koji svojim oporukama i ugovorima dogovara uređenje i opremanje toga oltara, iz ugovora što ga je 1456. godine potpisao s Andrijom Alešijem, kojega je zapisao u svojoj kancelariji Toma Stančić, a u kojem od Alešija naručuje izradu kamenih ogradica za oltar Tijela Kristova u katedralnoj crkvi sv. Marije, ${ }^{40}$ mogli bismo pret-

36 Tako se, primjerice, u jednom dokumentu iz 1471., koji je zapisao upravo Toma Stančić u svojoj bilježničkoj kancelariji spominje na sljedeći način: ...venerabili viro domino presbitero Thoma de Stanciis, canonico Arbense, tamquam honesta persona et notario publico... I. Pederin: Fond rapskih knezova i bilježnika, str. 30-31.

37 DAZd, RB, TS, kut. 3, sv. XI, fol. 165r-165v.

38 M. Montani: O radovima Furja Dalmatinca, str. 465. O postojanju zasebne kapele Tijela Kristova u katedrali govori i dokument (bez datacije) o sporu između Petra de Zaro, utemeljitelja hospitala Tijela Kristova i pripadajućega mu oltara u katedrali, i rapskih kanonika (zapisao ga je Toma Stančić). U njemu se navode obveze pojedinih stranaka, od kojih i obveza rapskih kanonika da održavaju pjevane mise u kapeli Tijela Kristova. ACA, Documenta dioc. Arbensis, Liber 43, fol. 161'-162'.

39 Više o razvoju svetkovine i oltara Tijela Kristova na području Venecije u XV. i XVI. st. vidjeti u: Nina Kudiš Burić: Oltari presvetoga Sakramenta u Savičenti i Osoru: problemi konteksta, tipologije, uzora i autora. U: Renesansa $i$ renesanse u umjetnosti Hrvatske: zbornik radova sa znanstvenih skupova "Dani Cvita Fiskovića održanih 2003. i 2004. godine (ur. Predrag Marković, Jasenka Gudelj), Institut za povijest umjetnosti u Zagrebu, Odsjek za povijest umjetnosti Filozofskoga fakulteta Sveučilišta, Zagreb 2008, str. 297-312, osobito str. 297-300.

40 DAZd, RB, TS, kut. 2, sv. IX, fol. 441-441a. 
postaviti da se radilo o kamenom, mramornom oltaru ukrašenom skulpturom. No kako u rapskim vrelima iz toga vremena ipak ne nalazimo potvrdu o izradi cjelovitoga kamenoga oltara, postoji mogućnost da je oltar Tijela Kristova u katedralnoj crkvi sv. Marije ipak bio drveni oltar, nalik onima u Veneciji, nabavljen u nekoj od radionica na Apeninskom poluotoku ili ipak izrađen na Rabu, a koji je donator naknadno odlučio ukrasiti kamenim ogradicama sa skulpturom. Da se pak uistinu radilo o oltaru, a ne kamenom tabernakulu kakvih je u Veneciji toga doba bio veći broj, govori činjenica da su se pred tim oltarom trebali održavati redoviti misni obredi. ${ }^{41}$

U razmatranju njegove druge važne uloge, prokuratora katedralne crkve, treba istaknuti da su prokuratori, slično kao i priori, bili pravni zastupnici svjetovnih ili crkvenih pojedinaca svih staleža ili pravni savjetnici i upravitelji ustanova (crkava, kapela, oltara, bratovština, lazareta ili hospitala), obično u drugim mjestima ili u samom gradu ili komuni Rabu, ukoliko sama stranka, sudionik u pravnom činu, nije bila prisutna u komuni ili gradu. Prokuratura se mogla odnositi na sve pravne poslove, pri čemu prokurator zastupa osobu ili ustanovu u svim pravnim predmetima, kao što su potraživanje dugovanja, zaštita vlasništva, sporovi vezani uz poslovanje i slično, a mogla se odnositi i na samo jedan, ugovorom definiran pravni posao, pri čemu je stranka izabrala prokuratora samo za nj. Često su u istočnojadranskim komunama tijekom razvijenoga i kasnoga srednjovjekovlja, kada su kontinuirano tekli radovi na izgradnji, uređenju i opremanju katedrala, postojala po dva prokuratora, pri čemu je jedan prokurator bio plemić, a drugi svećenik pripadnik Rapskoga kaptola. ${ }^{42}$ Zasigurno su takve prilike vladale i u vrijeme dok je Toma bio prokurator katedrale te je, posjedujući pravnu i financijsku okosnicu za upravljanje dobrima katedralne crkve, zasigurno utjecao na njezino uređenje te nabavku vrijedne liturgijske opreme. Nije poznato koliko je dugo Toma bio prokurator katedrale, no sigurno na toj dužnosti nije bio prije rujna 1457., kada se na toj dužnosti spominje svećenik Ivan

41 Tako je određeno, primjerice, u oporuci Petra de Zaro sastavljenoj 4. studenoga 1456. DAZd, RB, TS, kut. 2, sv. VIII, fol. 108r-110r.

42 O tome, primjerice, govori i sljedeći dokument, zabilježen 24. VII. 1497., koji donosi O. Badurina u svojoj Velikoj kamporskoj kronici: »U rapskoj katedrali čine krstionicu, koja je i danas tamo. Čitamo: „Arbi ... procuratores ecc. cathedr. arbensis, kanonik Mat. Picicus et nobilis vir ser Johanes de Dominis (dictus Bachinus) (Vazda su prokuratori katedrale bili: jedan kanonik i jedan sekularni plemić, a ovima biskup s rapskim knezom), ovi čine nagodbu s magistro Petro de Tragurio habit. Arbi. Petar će učiniti, una pila da batisterio dela piera de monte doro apresso a Rovigno ...la qual da esser lavorata a similititudine di pergola di dicta gescia ... cum le sue svaze ... atorno a oto cantoni in spatie. Per deba festa romana ..., exceptuando uno spatio di ditte nella qual die sculpir una misse san Zuane batista. la qual pila di esser in alteca si 3 et incavada e dintra via, al longeca pie tre marcho una quarta... la qual lavoro al ditta dieba dar compito a tute sue spese per tuto mese de novembrio ... et deba hav per sua me lire 100 de piculi.“ (Rab: Sudski A.: A. Georg Segota, 342. - Kampor Archiv: „Cronaca...“ 277.). Odorik Badurina: Velika kamporska kronika. Liber II, str. 73; O prilikama u Trogiru u razvijenom i kasnom srednjem vijeku vidjeti: Irena Benyovsky Latin: Razvoj srednjovjekovne operarije - institucije za izgradnju katedrale u Trogiru. Croatica Christiana periodica, 34(2010) 65, str. 1-18. 
de Migna. ${ }^{43}$ Jedini poznati dokument u kojem se Toma spominje na dužnosti katedralnoga prokuratora zapisan je 1462. i u njemu naručuje bačve potrebne za skladištenje vina katedrale. ${ }^{44}$ Tada, naime, naručuje izradu tres veges de rouore bonas et bene laboratas, odnosno tri bačve za vino od majstora Šimuna Dragoribe iz Raba, koji je bio magister botarius. ${ }^{45} \mathrm{U}$ istom se dokumentu Šimun obvezao izraditi spomenute bačve pro modios vigintiuno vini, dakle točno određene zapremine. ${ }^{46}$ Govori to o činjenici da je Toma kao prokurator katedrale vjerojatno bio zadužen za opskrbu vinom. Premda se u jednom kasnijem dokumentu, iz travnja 1475., više ne spominje u ulozi katedralnoga prokuratora, vidno je da je i dalje trgovao vinom. Tada je, naime, za svoje prokuratore izabrao spectabilis et gloriosus vir dominus Petrus Mudateo i svojega nećaka Tomazija de Stanze kojima je dao pravo da naplate novčanu svotu od ducatos tresdecim auri a magistro Iohanne Nigro organorum de Veneciis i to za preostali dio vina koji je Ivan Nigro kupio od Tome. ${ }^{47} \mathrm{U}$ tom naizgled šturom bilježničkom dokumentu zanimljiva je upravo veza kanonika Tome Stančića i orguljara ili orguljaša Ivana iz Venecije kod kojega je godinu dana ranije naručena izrada orgulja za potrebe rapske $\mathrm{crkve}^{48} \mathrm{i}$ koji se, kao što potvrđuju kasniji dokumenti, trajno nastanio na Rabu. ${ }^{49}$

Vjerojatno se pritom radilo o prvim orguljama koje su izrađene na Rabu i to vjerojatno za potrebe bogoslužja u katedralnoj crkvi. Istaknimo na ovom mjestu da

${ }^{43} \mathrm{U}$ rujnu 1457. su, naime, rapski biskup Ivan de Scaffa i prokurator rapske katedrale Ivan de Migna s jedne strane te Bartul Trogiranin (de Tragurio), prior dominikanskoga samostana sv. Nikole iz Kotora, s druge strane, potpisali ugovor prema kojem prior Bartul kupuje za svoj samostan jedan gradual i jedan antifonar, napisani po propisima dominikanskoga reda, a koji su se zasigurno nalazili u posjedu rapske katedrale. A. Vidaković: Tragom naših, str. 378. Autor članka nadalje pretpostavlja da su navedeni rukopisi, budući da su izrađeni za potrebe dominikanaca te se nisu koristili u rapskoj katedrali, ondje mogli dospjeti na dva načina. Oni su katedrali mogli biti ili poklonjeni ili je pak postojala katedralna pisarska radionica u kojoj su se izrađivali razni rukopisi prema narudžbama. U svakom slučaju, kako zaključuje autor, u rapskoj je komuni u XV. st. postojao veći broj neumatskih rukopisa. Ibid.

${ }^{44}$ DAZd, RB, AF, kut. 1, sv. V, fol. 18.

${ }^{45}$ Ibid.

${ }^{46}$ Sredinom XV. stoljeća jedan modij vina iznosio je oko 83 litre. Budući da je prokurator katedrale Toma Stančić naručio tri bačve, jasno je da je svaka od njih bila velika te da su imale zapremninu od po nekoliko stotina litara svaka. Sve zajedno imale su zapreminu od nešto više od 1600 litara. Nema sumnje da je za izradu bačvi takvih dimenzija bila potrebna prilična vještina majstora bačvara Šimuna Dragoribe.

47 DAZd, RB, AF, kut. 1, sv. IX, fol. 51a.

${ }^{48} \mathrm{O}$ tome svjedoči jedan notarski dokument koji je 1474. u svojoj bilježničkoj kancelariji zapisao notar Toma Stančić. I. Pederin: Svakidašnjica u Rabu, str. 31.

49 Tu činjenicu potvrđuje sljedeći podatak: »...rapski arciđakon Martin de Nimira imenuje 1493. kao komendator sv. Petra u Drazi Ivana Nigra doživotnim kapelanom kapele sv. Marije Magdalene i uživateljem dobara te crkve uz uvjet da mu odstupi 1/3 žita, drva, meda, vina i smokava. Od pomoći će dobiti samo par volova za oranje.« Ivan Pederin: Svakidašnjica u Rabu, str. 51. 
je upravo važan aspekt svetkovine Tijela Kristova, koja je u rapsku komunu i rapsku katedralnu crkvu uveden nastojanjem rapskoga patricija Petra de Zaro i Tome Stančića kanonika i notara dva desetljeća ranije, uz procesije i dramske prikaze, bio i razvitak crkvene glazbe te sve češće prakticiranje sviranja na orguljama u sakralnim prostorima. Upravo se, primjerice u Splitu, uz djelatnost bratovštine Tijela Kristova vezuje i izrada vjerojatno prvih orgulja u splitskoj katedrali početkom XVI. st. ${ }^{50} \mathrm{Za}-$ sigurno se i u Rabu izrada prvih orgulja za katedralnu crkvu može povezati uz slavljenje svetkovine Tijela Kristova, nedugo nakon osnutka hospitala i izrade njegova oltara te učvršćenja običaja slavljenja te svetkovine u katedralnoj crkvi. Nadalje treba istaknuti i to da se spomen Tome Stančića i orguljara Ivana Nigra iz Venecije u istom dokumentu može povezati s angažiranošću toga rapskoga svećenika oko izrade dotičnih orgulja. ${ }^{51}$

${ }^{50}$ Ivan Ostojić: Stara bratovština presv. Tijela Kristova u Splitu - prvi dio. Bogoslovska smotra, 45(1975) 4, str. 486.

${ }^{51}$ U bilježničkom dokumentu koji je zapisao notar Andrija Fajeta (DAZd, RB, AF, kut. 1, sv. IX, fol. 5la.) nije, doduše, posve jasno radi li se o majstoru (magister organorum) koji je samo izrađivao i popravljao orgulje ili je ujedno i svirao na njima. Vjerojatno se ipak pod ovim nazivom skriva profesija i izrađivača orgulja i svirača na njima te je tek kasnije došlo do razdvajanja ovih dviju profesija. Na taj se način, nasuprot mišljenju V. Brusića koji piše da se orgulje »u rapskoj ... stolnici... spominju već od XVI. stoljeća«, spomenom magistro organorum Iohanne Nigro de Veneciis i postojanja orgulja u Rabu te rad orguljaša u rapskoj katedrali sv. Marije pomiče u jedno stoljeće ranije, odnosno u 1474., kada je bila naručena njihova izrada, te 1475. kada ili još traje njihova izrada ili su možda već služile za potrebe bogoslužja. Više o pitanju izrade prvih orgulja u Rabu vidjeti: Vladislav Brusić: Otok Rab: geografski, historijski i umjetnički pregled sa ilustracijama i geografskom kartom Kvarnera $i$ Gornjeg Primorja (dalje: Otok Rab). Franjevački kamporski samostan sv. Eufemije, Rab 1926, str. 154; I. Pederin: Svakidašnjica u Rabu, str. 31, 127-129. Ovi podatci upućuju na to da je Rab tijekom XV. st. u glazbenom smislu bio vrlo prosperitetna komuna na našoj obali Jadrana, već i zbog činjenice da je cijena izrade orgulja bila vrlo visoka, a sama rapska Crkva morala je imati i stalno zaposlenoga svećenika ili laika orguljaša. Mišljenje da su orgulje u katedralnoj crkvi u Rabu postojale već u XV. st. izložio je i C. Fisković, koji navodi da se u arhivskim vrelima iz 1523. orgulje u katedrali spominju kao veoma trošne. Naime, te su godine rapski knez P. Malipietro, biskup i skrbnici rapske katedrale odlučili nabaviti nove orgulje za tu crkvu budući da su stare bile oštećene i dotrajale. Cvito Fisković: Iz glazbene prošlosti Dalmacije. Mogućnosti, 21(1974) 6-7, str. 711-764. (o orguljama na Rabu str. 723-724, dokumenti na str. 753-754). O postojanju orgulja već u XV. st. na Rabu govori i E. Stipčević. Ennio Stipčević: Arhiviranje tišine: kako je pjevala hrvatska Euridika?, Kolo, 4, 2006, str. 357-380, os. str. 367-368. Taj se autor, pozivajući se dijelom i na istraživanja I. Pederina (Uprava, crkva, politika i kultura na Rabu u XVI. stoljeću, Radovi Zavoda za povijesne znanosti HAZU u Zadru, 36, 1994, str. 125-180, os. poglavlje o glazbi na Rabu str. 156-158; Glazba na renesansnom Rabu, Arba: revija za Rabljane i njihove goste, 1, 1994, str. 27-28) pojašnjava da su se tijekom kasnoga srednjovjekovlja i ranoga novovjekovlja »lokalne crkvene vlasti i mletačka uprava u Dalmaciji brinuli o nabavci orgulja, a orguljaši su najčešće bili regrutirani iz Italije« (str. 367). Po svemu sudeći, orguljaši su dolazili na Rab upravo s područja Mletačke Republike, a kao i u ostalim dalmatinskim gradovima upravo su oni održavali nastavu u sklopu sjemeništa ili katedralnih škola (str. 367). U nastavku isti autor zaključuje da »grad Rab nabavlja orgulje već u 15. stoljeću, a od 1523, kada je odlučeno da se nabave nove orgulje, možemo kontinuirano pratiti kako su talijanski orguljaši službovali za potrebe stolne crkve. Što je još važnije, od početka 16. st. dokumentirano je glazbeno školstvo u Rabu. ...Rapski knez i generalni vikar 1556. su doveli orguljaša Maphea Chavaqa iz Muglie za godišnju plaću od 45 dukata, a on se pak obvezao svirati i podučavati pjevanju. Čini se da je orguljaš Benedetto Neruci iz Firenze, na dužnosti katedralnog orgu- 
Osim što je bio prokurator katedralne crkve sv. Marije, Toma Stančić se u rapskim dokumentima spominje i kao upravitelj i kapelan nekih drugih manjih crkava na Rabu. God. 1454. biskup Ivan de Scaffa dao mu je u nadarbinu kapelu sv. Petra de Nadre (S. Pietro de Nadre; de Nadra) koja se nalazila u sklopu šire pogrebne zone u neposrednoj blizini katedrale, a koja se u izvorima i literaturi spominje is titularima sv. Antuna i sv. Ivana Krstitelja. ${ }^{52}$ Ujedno je, prema bilježničkom dokumentu iz 1454., imao ius patronatus nad crkvom sv. Katarine u Kaldancu (de Capodanzo)..$^{53}$ Iz nešto kasnijega vremena potječe dokument s inventarom nekretnina iste crkve koje je zapisao sam Toma, navevši pritom više kuća i zemljišta na području grada Raba i rapskoga distrikta, što upućuje na to da je kao upravitelj dobara te crkve raspolagao priličnim materijalnim i financijskim bogatstvom, koje je nesumnjivo mogao uložiti u obnovu i liturgijsko opremanje te građevine. ${ }^{54}$

Poznate nam isprave ne odaju detalje takva Tomina djelovanja, no mnogi bilježnički dokumenti iz istoga razdoblja pokazuju kakve je obveze imala osoba koja je stekla ius patronatus nad određenom crkvom. Dobar je primjer bilježnička isprava zapisana u svibnju $1469.5^{5}$ u kojoj se govori o dodjeli patronatskoga prava nad crkvom

ljaša od 1552. do 1560, uživao osobit ugled....Rapska „scola di musica“ čini se da je bila u potpunosti usmjerena na glazbeno školovanje svećenstva, a da je primarni zadatak bilo osposobljavanje pjevača pri bogoslužju. Po tome što se od orguljaša tražilo da podučavaju „canto fermo e figurato“ proizlazi da su se u crkvama pjevali gregorijanski napjevi ali i višeglasje. Rapska glazbena škola bila je u hrvatskim relacijama upravo jedinstvena takva ustanova, specijalizirana za glazbenu izobrazbu tijekom 16. stoljeća.« E. Stipčević, str. 367-368. (ujedno vidjeti članak E. Stipčevića: Iz hrvatske renesanse: o odgoju i glazbi. Croatica et Slavica Iadertina, 11(2015) 1, str. 105-117, podatci o glazbenim prilikama na Rabu doba renesanse na str. 107-108)

52 Toma Stančić postaje njezin kapelan 1454. godine, o tome v. u: DAZd, RB, TS, dok. datiran 28. VII. 1454, fol. 293; I. Pederin ističe da je »dotičnu nadarbinu kanonik Toma Stančić dobio sine cura, što znači da on u toj kapeli nije bio dužan čitati misu i obavljati druge dušobrižničke dužnosti. Bio je to renesansni običaj koji se prije svega odnosio na rimske prelate što su dobivali prihode iz udaljenih posjeda i crkava u kojima nisu boravili, pače ih nisu nikad ni vidjeli.« I. Pedrin: Svakidašnjica u Rabu, str. 27-28. Više o položaju i historijatu kapele sv. Petra de Nadre (de Nadra) vidjeti u: Natalia Beg: Rapska obitelj Dokulo: o heraldičkom znaku, njihovoj vezi s otokom Krkom i obnovom kapele pokraj rapske katedrale. Krčki zbornik, 75, 2019, str. 22-23, 25-29; Ana Konestra, Fabian Welc, Paula Androić Gračanin, Kamil Rabiega, Bartosz Nowacki, Agnese Kukela: Tipologija i organizacija otočnih naselja Raba kroz dijakronijski pristup - Prvi podaci multidisciplinarnih istraživanja. Godišnjak Instituta za arheologiju, 16 (2020), str. 238; Miljenko Domijan: Rab. Grad umjetnosti. »Barbat«, Zagreb 2001, str. 169. (fotografija kapele izrađena prije njezina rušenja poč. XX. st., na pročelju je antička glava Jupitera); Wilhelm Schleyer: Arbe. Stadt und Insel, ein Schatzkästlein der Natur und Kunst in Dalmatien. Mit 145 Abbildungen. C. W. Kreidel's Verlag, Wiesbaden 1914, str. 44 (fotografija kapele).

53 DAZd, RB, TS, dok. datiran 28. 7. 1454, fol. 293.

${ }^{54}$ Sam je dokument bez datacije, ali je riječ o prijepisu dokumenta koji je nastao vjerojatno 1460 -ih (budući se Toma Stančić u njemu naziva priorom /oltara op.a./ Tijela Kristova), s dopunama iz kasnijega razdoblja (iz 1480-ih). ACA, Documenta dioc. Arbensis, Liber 43, fol. 158-158'.

55 DAZd, RB, AF, kut. 1, sv. VII, fol. 19a. 
sv. Marije u Runjki. ${ }^{56}$ U njoj se isprva pojašnjava kako je rapski biskup Ivan de Scaffa, prema ispravi koju je u svojoj bilježničkoj kancelariji ranije zapisao Toma Stančić, dao ius patronatus nad crkvom sv. Marije u Runjki rapskom građaninu i stolarskom majstoru (magister marangonus) Damjanu. Iz originalnih pak, Tominih zapisa, koji su sačuvani u prijepisu u Arhivu bivšega Rapskoga kaptola, saznajemo da je kapelan te crkve u vrijeme sastavljanja Tominih notarskih dokumenata bio rapski svećenik Ivan de Migna.$^{57}$ Iz tih dvaju ranijih Tominih zapisa, kao i iz notarske isprave koju je zapisao Andrija Fajeta 1469., zorno se vidi koje su bile osnovne obveze patrona crkve jer je Damjan bio obvezan obnoviti i održavati rečenu crkvu odnosno kapelu te uredno upravljati njezinim financijama. ${ }^{58}$ Međutim, kako stoji u Fajetinoj ispravi, Damjan nije ništa napravio in reparatione, murare et coperire spomenute crkve i to, kako se izričito kaže, propter paupertatem et inpossibilitatem suum, dakle zbog osobnoga siromaštva i nemogućnosti da obavi spomenute radove. ${ }^{59}$ Budući da drvodjelja Damjan, očigledno iz objektivnih razloga, nije mogao obavljati svoju patronatsku dužnost, rapski biskup Ivan de Scaffa odlučio je ius patronatus nad ovom crkvom predati brijaču odnosno ranarniku (barbitonsor) Damjanu Chiola iz Raba koji se ovom ispravom obvezao crkvu sv. Marije aptare, reparare et copertire jer je bio u boljim financijskim i materijalnim mogućnostima od Damjana. ${ }^{60}$

Iznimno je važno za rapsku kulturu druge polovice XV. st. i podatak da je Toma 1482. zapisao, kako sam kaže »vjerodostojan prijepis ... kojem ništa nije dodavao niti mijenjao kako ne bi mijenjao smisao«, tri victoriae, kraće hagiografsko djelo o nebeskom zaštitniku i posredniku Raba sv. Kristoforu, naslovljeno Historia sancti Christophori Martyris, ${ }^{61}$ temeljeći ga na tekstu što ga je početkom XIV. st. sastavio rapski biskup Juraj de Hermolais. ${ }^{62}$ Svjedoči to o iznimnoj upućenosti Tome Stančića

56 O ovome toponimu opširnije vidi: Nikola Vuletić: Bilješke iz rapske povijesne toponimije: toponimi bez suvremenih potvrda (dalje: Bilješke iz rapske povijesne toponimije. Folia onomastica Croatica, 29, 2020, str. 239-241.

57 Riječ je o prijepisu dvaju dokumenata koje je zapisao notar Toma Stančić, prvi od njih datiran je 2. III.1460., a drugi 11. VIII. 1460. ACA, Documenta dioc. Arbensis, Liber 43, fol. 108-108'.

58 Ibid; DAZd, RB, AF, kut. 1, sv. VII, fol. 19a.

59 Ibid.

60 Ibid.

61 D. Farlati: Illyricum sacrum, sv. 5. Prijepisi vezani uz spomenute victoriae nalaze se na str. 231-232, 233, 235.

62 U Rabu je neprikosnoveni protektor komune tijekom razvijenoga i kasnoga srednjega vijeka bio trostruki nebeski spasitelj rapske komune - sv. Kristofor, zaštitnik protiv epilepsije, vremenskih nepogoda i, što je osobito važno, tada sveprisutne kuge, ali i zaštitnik pomoraca i putnika. U srednjem je vijeku bilo uvriježeno vjerovanje da svatko onaj koji nekoga dana, u bilo kojoj prilici i na bilo kojem mjestu, vidi kip ili sliku sv. Kristofora, neće umrijeti iznenadnom smrću. Zato je i u Rabu na više mjesta bio uklesan kip sv. Kristofora. Početak pisanoga utvrđivanja svečeva kulta pada u razdoblje biskupovanja Cresanina Domane u drugoj polovici XI. st., a njegovo hagiografsko djelo o Kristoforu poznato je iz 
u vjersku kulturu kasnosrednjovjekovnoga Raba, kao i o njegovoj humanističkoj djelatnosti usmjerenoj prepisivanju starih rukopisa, u ovom slučaju starijih redakcija životopisa zaštitnika grada i komune sv. Kristofora, koje je, kao što je zapisano, na povjerenje dobio od nekoliko rapskih plemića koji su bili zaduženi za čuvanje relikvija i tekstova vezanih uz povijest toga svetca. ${ }^{63} \mathrm{U}$ prilog njegovoj dobroj upućenosti u hagiografsku baštinu rapske komune, kao i inventare dobara pojedinih rapskih samostana i crkava govori i činjenica da je upravo on 1475. izradio popis Inventara benediktinske opatije sv. Petra u Supetarskoj Drazi i sv. Stjepana u Barbatu bogatoga različitim liturgijskim tekstovima. ${ }^{64} \mathrm{Uz}$ to, više ga autora povezuje uz izradu jednoga ili čak dva sačuvana antifonara, odnosno zbornika crkvenih napjeva, koji su izrađeni u rapskoj komuni u XV. st., po svemu sudeći u vrijeme vrlo razvijenoga interesa za crkvenu glazbu. ${ }^{65}$ Jedan od tih antifonara možda je onaj čiju je izradu 1445 . oporučno naručio rapski arhiđakon Antun Galzigna. ${ }^{66}$ Zanimljivo je da se upravo u jednom od antifonara, nastalom približno $u$ istom razdoblju, kojem nije zabilježen autor, a koji je nastao unutar rapske biskupske kurije, nalaze dijelovi koji su posvećeni svetkovini Tijela Kristova. S obzirom na to da se radilo o novoj svetkovini, koja je upravo u to doba prihvaćena na Rabu (a vidjeli smo da su upravo rapski patricij Petar de Zaro i Toma Stančić, kao osoba od njegova povjerenja, promicali i popularizirali taj kult na

prijepisa koje je početkom XIV. st. zapisao rapski biskup Juraj de Hermolais (1292-1313). Upravo su Miracula ili Historiae sancti Christophori Jurja de Hermolais dale dodatni poticaj porastu popularnosti kulta rapskog protektora jer su iz njegove pismeni Rabljani, ali i svi ostali vjernici tijekom održavanja misa, mogli saznati o Kristoforovoj čudesnoj zaštiti njihova grada Raba. Iako opsegom prilično kratak, tekst predstavlja tipičan uradak hagiografskoga žanra toga razdoblja. Meri Kunčić i Zoran Ladić: Rabljani u tisućugodišnjem okrilju svetoga Kristofora. Hrvatska revija, 3(2003) 2, str. 85-89. Zanimljivo je u kontekstu kulta sv. Kristofora spomenuti da se kao mjesto sastavljanja odnosno data topica više rapskih notarskih isprava iz druge polovice XV. st. spominje da su zapisane kod katedralne crkve in platea Arbi apud ymaginem sancti Christophori Vidi npr.: DAZd, RB, TS, kut. 2, sv. VII, fol. 312.

${ }^{63}$ D. Farlati: Illyricum sacrum, sv. 5, str. 231-235; Giuseppe Praga: La traslazione di S. Niccolò e i primordi delle guere normanne nell'Adriatico. U: Scritti sulla Dalmazia, 2. Rovigno-Fiume-Trieste 2014, str. 97-267, osobito str. 100-103.

${ }^{64}$ Prema pisanju S. Potočnjak, proučavanje hagiografske baštine Raba još je u začecima, a u rukopisnoj tradiciji prevladavaju kultovi Djevice Marije i sv. Kristofora. No, proučavajući sadržaj Inventara benediktinske opatije sv. Petra u Supetarskoj Drazi i sv. Stjepana u Barbatu (Inventario dell'abbazia benedettina di San Pietro a Supetarska Draga e di Santo Stefano a Barbat), koji je 1475. zapisao upravo Toma Stančić, a u kojem se, među ostalim, navodi »uno legendario de litera beneventana, [...] uno lectional de lettera beneventana in la qual si cantan evangeli e pistole« autorica zaključuje da ne treba isključiti da su u drugoj polovici XV. st. u rapskoj komuni postojali legendarij i sanktoral s popisom službi za slavljenje pojedinih svetaca te vjerojatno jedan sveobuhvatniji hagiografski kodeks kao što je martirologij (pasional). Saša Potočnjak: »Facta est «. Frammenti apocrifi del Nuovo Testamento dall'isola di Arbe, u: La Serenissima via mare - Arte e cultura tra Venezia e il Quarnaro (ur. Valentina Baradel, Cristina Guarnieri). Padova University Press, 2019., str. 90, sl. 2 (faksimil stranice Inventara).

${ }^{65} \mathrm{O}$ glazbi u rapskoj komuni u XV-XVI. st. postoji obimna literatura, vidjeti bilj. 51.

${ }_{66}$ Albe Vidaković: Tragom naših srednjovjekovnih neumatskih rukopisa (dalje: Tragom naših). Ljetopis FAZU, 67, 1963, str. 364-392, osobito str. 375-377. 
Rabu), vrlo je vjerojatno da se nastanak tog antifonara također može smjestiti u blisko vremensko razdoblje, ali da bi se pouzdano utvrdila veza Tome Stančića, uz njegovu izradu potrebno je provesti daleko opsežnija istraživanja. ${ }^{67}$ Nadalje, Tomi se pripisuje izrada prijepisa antifonara, vjerojatno iz 1476., u kojem se kao prepisivač navodi $»$ presbiter $\mathrm{T} . . .{ }^{6}{ }^{68}$

Po svemu sudeći Toma je različitim segmentima svoje djelatnosti aktivno kreirao kulturnu klimu onodobnoga Raba, jednako kao javni bilježnik i kao svećenik, odnosno obrazovani kanonik koji je, kao što smo vidjeli, dobro poznavao rapsku crkvenu i religioznu pisanu baštinu. Nesumnjivo je takvim svojim djelovanjem među rapskim stanovništvom pridonio prihvaćanju i širenju suvremenih mu religijskih, liturgijskih i ikonografskih strujanja u glazbenoj, pisanoj i likovnoj kulturi rapske komune svojega doba. Bilježnik Toma Stančić djelovao je do $1491 .{ }^{69}$ pa je vjerojatno, nedugo potom, u poodmakloj dobi, završio njegov životni put. ${ }^{70}$

\section{Toma Zangarel, kanonik, prior crkve i hospitala sv. Katarine na Komrčaru}

Prema podatcima iz rapskih bilježničkih spisa, u rapskoj se komuni često javlja u ulozi priora i patrona više rapskih kapela i crkava. Zarana se spominje, od druge polovice 1430-ih pa sve do kasnih 1470-ih, kao prior crkve sv. Katarine na Komrčaru. Povijest crkve sv. Katarine vezana je uz povijest franjevačkoga samostana na Komrčaru koji je tijekom razvijenoga i kasnoga srednjovjekovlja imao karitativnu ulogu u rapskoj zajednicu te se ondje nalazio hospital u kojem su se zbrinjavali siromašni i bolesni. ${ }^{71}$ Po svemu sudeći, u drugoj polovici XV. st., s porastom trgovačkoga prometa Raba, taj je hospital bio prenamijenjen u lazaret pa se otada u izvorima, u brojnim oporučnim ostavštinama, njegovu uređenju, kao i uređenju pripadajuće mu crkve sv.

67 Ibid.

68 Do toga je zaključka došao A. Badurina, s tim da je vjerojatnijom godinom, zasigurno zbog nečitkosti samoga izvora, smatrao 1426. Aleksandar Stipčević: Socijalna povijest knjige u Hrvata: knjiga 1. Srednji vijek. Školska knjiga, Zagreb 2004., str. 58. Ta godina, međutim, ipak ne bi odgovarala vremenu djelovanja notara Tome Stančića.

69 Robert Leljak, Sumarni Inventar. Rapski bilježnici 1403-1875, br. fonda: HR DAZD 28. Državni arhiv u Zadru, Zadar 1994., str. 2.

70 Prema I. Pederinu, kanonik Toma Stančić umro je vjerojatno 1492. ili 1493., a posljednji poznati dokument u kojem se spominje kao prokurator kanonika i primicerija Francesca de Petramala iz Brescije koji uživa nadarbine nekih brdskih kapela u rapskoj komuni zapisan je 1492. Sljedeće je godine, nakon njegove smrti, Rapski kaptol primio Antu Briciusa iz Zadra za kanonika. I. Pederin: Svakidašnjica $u$ Rabu, str. 34-35.

71 Više o povijest toga hospitala vidjeti u: M. Kunčić: Dalmatinski patricijat i socijalno kršćanstvo, str. 39-43. 
Katarine, naziva i lazaretom sv. Katarine na Komrčaru. ${ }^{72}$ Nema sumnje da je upravo Toma Zangarel, kao dugogodišnji prior crkve sv. Katarine, koji je po svemu sudeći bio i prior obližnjega hospitala, ${ }^{73}$ imao važnu ulogu u upravljanju oporučnim legatima i uređenju te crkve i ubožnice.

U najranijem poznatom spomenu na toj dužnosti, iz 1439., ${ }^{74}$ Toma Zangarel spominje se kao svećenik i prior Sti. Francisci de Comerzar koji u prisutnosti svjedoka i uz dopuštenje Rapskoga kaptola prima dva redovnika trećoredca na stan, određujući im kao obvezu obrađivanje pripadajućih zemljišta. ${ }^{75} \mathrm{No}$, čini se ipak da prihodi hospitala nisu bili dostatni za njegovo normalno uzdržavanje pa se zgrada hospitala urušila, a njezinoj obnovi pristupilo se sredinom XV. st. zahvaljujući oporučnom novčanom legatu patricija Marina Baduarius. ${ }^{76}$ Kao prior sv. Katarine na Komrčaru, Toma se spominje i u kasnijem razdoblju, u vrijeme kontinuirane obnove crkve i hospitala, $1446 .{ }^{77} 1451 .{ }^{78} 1452 .{ }^{79}$ i $1461 .,{ }^{80}$ te u studenom $1464 .$, kada je zabilježen u jednom bilježničkom dokumentu kojim daje drvodjeljskom majstoru (magister marangonus) Paulinu, sinu Marka i Dobrule iz Raba, duos suos boues aratores usque ad vnum annum, dakle dva bika za oranje na godinu dana i to uz naknadu od ducatos duobus auri boni. ${ }^{81}$

72 I. Pederin: Svakidašnjica u Rabu, str. 45. Na temelju postojećih arhivskih vrela ne može se zaključiti je li dotična crkva, koja je jednako kao i pripadajući joj hospital odnosno lazaret, imala dva titulara - sv. Franju i sv. Katarinu, a koji su zahvaljujući mnogim oporučnim legatima iz druge polovice XV. st. obnovljeni, bila posvećena sv. Katarini Aleksandrijskoj ili sv. Katarini Sijenskoj. No, budući je kult sv. Katarine Aleksandrijske bio prisutan na Rabu i tijekom ranijih stoljeća (o tome primjerice vidi: Dušan Mlacović: Slika svete Katarine. Otium, 4(1994) 1-2, str. 31-34), a postojanje dvaju navedenih titulara posvjedočeno je već početkom XIV. st. (P. Runje: Franjevci trećoreci-glagoljaši, str. 333), zasigurno je ipak riječ o sv. Katarini Aleksandrijskoj, svetici koja je bila prihvaćena jednako unutar dominikanske kao i franjevačke redovničke zajednice. Kult sv. Katarine Sijenske znatno je mlađi te se počeo širiti nakon njezine kanonizacije 1461., i to uglavnom među dominikancima. U srednjem vijeku sv. Katarina Aleksandrijska štovana je kao zaštitnica djevojaka, u renesansnom slikarstvu čest je motiv njezinih zaruka s Kristom. Atributi su joj kotač i mač kao simboli mučeništva, kruna kao znak kraljevskoga podrijetla, palmina grana kao simbol pobjede i knjiga u ruci kao simbol učenosti. Leksikon ikonografije, liturgike $i$ simbolike zapadnog kršćanstva. Sveučilišna naklada Liber-Kršćanska sadašnjost-Institut za povijest umjetnosti, Zagreb 1979, str. 324-325.

73 P. Runje: Franjevci trećoreci-glagoljaši, str. 333.

74 Ibid.

75 Ibid.

76 Mirko Dražen Grmek: Povijest zdravstva na Rabu. Medicinar, 3(1949) 6, str. 300.

77 I. Pederin: Svakidašnjica u Rabu, str. 48.

78 Ibid., str. 51.

79 Ibid., str. 58.

80 Ibid., str. 33.

81 DAZd, RB, AF, kut. 1, sv. VI, fol. 12. 
Posljednji poznati dokument u kojem se na dužnosti priora priorata sv. Katarine na Komrčaru spominje njegova je oporuka iz $1478 .^{82}$

Ujedno se spominje kao upravitelj i patron nekih drugih manjih crkvica na Rabu. God. 1452. rapski patricij Ivan Dominis pok. Damjana, kao nositelj patronatskoga prava nad crkvom sv. Marije od Mira na Katurbu (in Catribo), ${ }^{83}$ izabrao ga je za upravitelja (rektora) te crkve. ${ }^{84}$ God. 1461. stekao je ius patronatus nad crkvom s. Bartholomei de Monte. ${ }^{85}$

Iz izvora su poznate tri njegove oporuke, iz 1452., 1462. i 1478., koje s jedne strane svjedoče o važnosti hodočašća u Tominom svećeničkom djelovanju, a s druge strane o njegovoj skrbi, kako za vlastitu obitelj tako i za mnoge rapske sakralne i karitativne ustanove.

Iz najranije njegove poznate oporuke, zapisane u svibnju 1452, doznajemo da venerabilis dominus presbiter Thomas de Çancarella prior sancte Catharine de Camarcarios sastavio tu ispravu neposredno pred odlazak na hodočašće u Svetu zemlju, gdje je namjeravao posjetiti Kristov grob. ${ }^{86}$ Oporuka je sastavljena u strahu od doista realnih opasnosti koje su ga mogle zadesiti na dalekom pomorskom i kopnenom putovanju u Palestinu (nevrijeme na moru, epidemija na brodu, opasnost od gusara i osmanskih pomorskih ophodnji) te je u njoj rasporedio svoju imovinu, dajući je na raspolaganje izvršiteljima, biskupu Ivanu de Scaffa, zatim Ivanu, opatu samostana sv. Petra u Supetarskoj Drazi i patriciju Damjanu de Hermolais pokojnoga Jakova. Dio njegova novca i imovine pritom je trebao ići samim izvršiteljima, a dio je trebao biti raspoređen na sljedeći način: katedralnoj crkvi sv. Marije ostavlja 25 dukata kao i jedan svoj vinograd koji se nalazi in Cameschaglio, ${ }^{87}$ nećakinji Menculi (Menzula, Menci) ostavlja 20 dukata pro suo maritare; 10 dukata ostavlja crkvi sv. Katarine čiji

82 24. 5. 1478. Venerabilis dominus Thomas de Zanzarellis canonicus arb. et prior loci prioratus s. Cat. de Chamenzario, čini test. - Među ostalim stvarima reliquit heremitis et fratribus morantibus in loco s. Chatarine prioratus suprascripti unam eius canipam sub capelle s. Elene. Domui de Lazareto 1 duc. auri. Nasljedniku naređuje da pođe za nj osobno u Rim i uzme još 1 osobu sobom, i da pođu sv. Fr. u Asiz i Gospi od Rakanata. Nasljednik neka u roku od 5 god. pođe sam ili neka pošalje drugoga, na Isusov grob u Jeruzalem. Zato ostavlja 50 dukata. (Rab: Sud. A.: A. Faieta, IX., 1022.). Odorik Badurina: Velika kamporska kronika. Liber II, str. 34.

83 Danas Trg slobode (Pjaceta)

84 Premda na samom dokumentu stoji datacija 26. XII. 1452., s obzirom na to da se nova godina računala od Božića (stilus nativitatis) ispravna bi datacija bila: 26. XII. 1453. ACA, Documenta dioc. Arbensis, Liber 43, fol. 84. nija na Rabu.

85 I. Pederin: Svakidašnjica u Rabu, str. 33; riječ je o toponimu na području današnjih Munda-

86 DAZd, RB, TS, kut. 2, sv. VI, fol. 55a-56.

87 Riječ je o toponimu u rapskom distriktu u predjelu današnjega Banjola. Vidjeti: N. Vuletić: Bilješke iz rapske povijesne toponimije, str. 245. 
je bio prior, a u slučaju da crkva ne dobije taj novac, njime treba sagraditi kuću za stanovanje pustinjaka; svom nećaku Ivanu ostavlja jednu manju kuću. Uz to, svim svojim dužnicima oprostio je trećinu njihova novčanoga duga, od ostalog što su mu dužni daje polovicu za obnovu katedrale sv. Marije, dio novca ostavlja siromasima, a osam dukata ostavlja za obnovu biskupskoga dvora u Rabu. Nadalje, bičevalačkoj bratovštini sv. Kristofora ostavlja 12 zlatnih dukata, nećaku Ivanu daruje tri bika za oranje i dvije krave, nećakinji Menculi jedan vinograd u Banjolu, a Rapskom kaptolu 50 libara i tri velike bačve. Univerzalnim nasljednicima imenuje svoju sestru Antoninu, kao i nećake Ivana, Nikolu i Matiju te nećakinju Menculu.

Već iz ove oporuke vidljivo je da se Tomina pobožnost izrazito uklapala u kasnosrednjovjekovni vjerski senzibilitet, u čijem je središtu topos imitatio Christi, s naglaskom na brizi o siromašnima, bolesnima, starima, djeci i drugim pojedincima i skupinama koje su smatrane najranjivijima u urbanim sredinama. Temelje toga senzibiliteta postavili su mendikantski redovi već u XIII. st. širenjem ideje o siromašnom, skromnom i jednostavnom životu kroz motiv vita evangelica et apostolica. U XV. st. ta je pobožnost još trajala, ali je obogaćivana u skladu s kriznim povijesnim okolnostima kao što su epidemije kuge, ratovi i periodi izrazite oskudice, koji su utjecali na povećan mortalitet stanovništva u gotovo svim dalmatinskim komunama. Upravo u to vrijeme ojačali su i svetački kultovi, poput onih sv. Bernardina i sv. Katarine iz Siene, koji su poticali skrb o najosjetljivijim skupinama urbanih sredina, posebice mladim djevojkama. Stoga su oporučitelji mnogim legatima nastojali poduprijeti ovu ideju darivanjem manjih ili većih svota novca ili drugih stvari za udaju siromašnih djevojaka samo kako bi njihov grad sačuvao perspektivu života, a koja je bila ugrožena i novim čimbenikom, sve učestalijim osmanskim upadima u zaleđa dalmatinskih gradova već od prve polovice XV. st. te odvođenjem radno sposobnoga seoskoga stanovništva i djece u ropstvo. Upravo su XIV. i XV. st. vrijeme u kojem se kršćanska pobožnost kreirala kroz doticaj sa stvarnim povijesnim okolnostima. No, ono što je najvažnije jest da pobožnost kako je možemo promatrati kroz oporuke, ali i druge izvore, više nije bila povezana isključivo s darivanjem poznatih, pomaganjem prijatelja ili rodbine, dakle pobožnost više nije bila iskazivana samo prema bliskima. Postala je izričajem anonimnosti jer su oporučitelji darivali nepoznate osobe u hospitalima i leprozorijima, na usamljenim mjestima nastanjene heremite i rekluze, koje osobno nisu poznavali. Dakle, kršćanstvo se, kako pokazuje i ova oporuka, uzdignulo na još višu razinu - solidarnost i milosrđe, ne samo prema poznanicima, članovima obitelji i prijateljima već i prema nepoznatima, anonimnima. Naravno, kako se oporukom moralo riješiti i pravo pitanje nasljeđivanja nekretnina te izbora univerzalnih nasljednika, Tomina oporuka nužno je okrenuta i prema bliskoj mu rodbini, počevši od njegove sestre Antonine.

God. 1462., prije putovanja u Veneciju, dao je sastaviti svoju drugu oporuku, ponovno u bilježničkoj kancelariji Tome Stančića, kanonika i notara, koji je jedan od 
izvršitelja njegove oporuke. ${ }^{8}$ Upravo nam ta Tomina oporuka pruža mnoge podatke o njegovim interesima, djelovanju. Sastavljena je, kako saznajemo iz samoga teksta, u vrijeme dok je još uvijek bio prior crkve sv. Katarine na Komrčaru, neposredno prije njegova odlaska u Veneciju, u strahu od putovanja morem. ${ }^{89}$ Imamo li na umu sve dužnosti koje je do 1462. obnašao, ne iznenađuje što ga u njegovoj oporuci iz svibnja te godine notar Toma Stančić titulira kao venerabilis vir dominus presbiter, ${ }^{90}$ a što iskazuje opće društveno poštovanje prema kanoniku Tomi u rapskoj sredini.

O samim razlozima njegova putovanja oporuka nam ne pruža podatke, ali možemo, dakako, pretpostaviti da je Toma ondje putovao ili iz vjerskih, diplomatskih ili iz poslovnih razloga. Sasvim je razložno pretpostaviti da je kao istaknuta osoba rapske crkvene hijerarhije, koja je u tom trenutku već dugi niz godina obnašala istaknutije dužnosti priora i upravitelja pojedinih crkvenih i karitativnih ustanova, putovao u Veneciju kako bi obavio nekakav posao vezan uz svoje svećeničke dužnosti kao rapskoga kanonika, sudjelovao u hodočašću ili nekom vjerskom događaju, ili kako bi dogovorio neki posao vezan uz opremu i uređenje karitativnih i crkvenih ustanova o kojima je skrbio, i to u samom središtu kulturnih i umjetničkih zbivanja Mletačke Republike. Bilježnički dokumenti iz nešto kasnijega razdoblja svjedoče i o tome da je Toma imao razvijenu poslovnu, osobito trgovačku djelatnost pa je opravdano pretpostaviti da je ponekad povezivao svoj trgovački interes sa skrbi o opremanju pojedinih sakralnih i karitativnih ustanova te $u$ Veneciji sklapao različite poslove. Konkretnih dokumenata koji bi potvrđivali njegovu poslovnu djelatnost upravo u Veneciji zasada nemamo, ali više bilježničkih isprava s područja Raba iz toga i nešto kasnijega razdoblja govore o njegovoj razgranatoj poslovnoj djelatnosti. Kao trgovac vinom spominje se u više dokumenata; u kolovozu 1465. bilježnik Andrija Fajeta zapisao je ugovor kojim je faber Vitus habitator Arbi kupio vino od Tome, priora crkve sv. Katarine u vrijednosti od 18 libara malih. ${ }^{91}$ Prema nešto kasnijem dokumentu, Toma, prior sv. Katarine, udružio se 1468. sa stanovitim Jurjom Bukšom te mu dao 150 libara malih kako bi otišao in partibus Sclavonie i od Ivana de Corbavia kupio kože te ih donio u Rab.92 Juraj je pritom obećao da će prioru Tomi isplatiti polovicu

88 DAZd, RB, TS, kut. 3, sv. XI, fol. 165r-165v.

89 Que omnia considerans venerabilis vir dominus presbiter Thomas, prior ecclesie sancte Catharine de Caminzario ac canonicus Arbensis, sanus quidem mentis, corpore et intellectu, scilicet profecturus Venetias timens pericula mortis et abintestatus decedere bonaque sua inordinata relinquere, hoc suum vltimum et irreuocabile testamentum facere procurauit... Iz ovih je riječi razvidno da je Toma dijelio opći strah od bilo koje vrste putovanja morem, pa čak i kada se radilo o relativno kratkoj plovidbi do Venecije. DAZd, RB, TS, kut. 3, sv. XI, fol. $165 \mathrm{r}$

90 DAZd, RB, TS, kut. 3, sv. XI, fol. 165r-165v.

91 DAZd, RB, AF, kut.1, sv.VI, fol. 26a.

92 DAZd, RB, AF, kut. 1, sv. VII, fol. 9. 
dobiti od prodaje koža. ${ }^{93}$ Nesumnjivo je Toma, na što će više svjetla baciti i analiza ove oporuke, bio vješt u stjecanju profita, što, premda je bio svećenik, nije odudaralo od životnoga stila mnogih pojedinaca njegova statusa u ostalim komunalnim društvima na istočnoj obali Jadrana..$^{94}$ Poznavanje crkvenoga i svjetovnoga prava dodatno ga je činilo okretnim u sklapanju različitih poslovnih ugovora. No, pritom treba naglasiti da je Toma, kako proizlazi iz njegovih biografskih podataka i stava prema svojim obvezama vezano uz crkvene i karitativne ustanove, barem podjednako brinuo za opće društvene i za osobne potrebe.

Osim o razlogu sastavljanja oporuke u svibnju 1462., doznajemo i tko su bili izvršitelji njegove oporuke, tj. osobe koje su trebale dovršiti sve Tomine pravne poslove koji bi ostali iza njegove smrti. Tu je ulogu dodijelio rapskom biskupu Ivanu de Scaffa, zatim kanoniku i bilježniku Tomi Stančiću te dugogodišnjem rapskom bilježniku Andriji Fajeti, kojega naziva svojim kumom, mecenom i pokroviteljem, dakle pripadnicima crkvene i svjetovne elite rapske komune. ${ }^{95} \mathrm{Za}$ mjesto pokopa, ukoliko umre na Rabu, odabrao je groblje pokraj crkve sv. Petra de Nadre, gdje je želio biti pokopan u skladu sa svojim statusom i prema odredbama izvršitelja oporuke. ${ }^{96}$

Svakako je u ovom kontekstu vrlo zanimljiv dio oporuke koji govori o njegovim novčanim darivanjima pojedinim rapskim crkvenim i karitativnim ustanovama. Katedralnoj crkvi sv. Marije u Rabu ostavo je oporučno priličnu svotu od 20 zlatnih dukata te jednaku svotu Rapskoj biskupiji. ${ }^{97}$ Kako nadalje saznajemo, taj iznos od ukupno 40 dukata, trebao je isplatiti ser Zedolino de Zudenicho na ime svojega duga prema Tomi ${ }^{98}$ Financijska potpora izgradnje sakralnih ili solidarnih ustanova jedan je od važnijih aspekata pobožnosti ovoga doba jer se dobro uklapa u koncept civitas sacra. U Šibeniku i Poreču oporučitelji pomažu izgradnju katedrale, ali i drugih crkava, kapela i oltara, a istovremeno se u Zadru, Trogiru i Rabu podupire izgradnja novih hospitala i drugih karitativnih i solidarnih ustanova. I u tom

93 Ibid.

94 Ivan Pederin: Commercio, economia, pesca, arti e mestieri in Arbe nel Quattrocento. Archivio storico italiano (Firenze), 147, 1989., str. 216.

95 ...In quo quidem testamento primo et ante omnia instituit suos procuratores, fideicommissarios et huius sui vltimi testamenti et vltime voluntatis executores reuerendum in Christo patrem et domino domino Iohannem Scaffa, Dei et apostolice sedis gratia episcopum Arbensis, me presbiterum Thomam notarium et ser Andream Foeta compatrem suum ad exequendum omnia et singula in presenti suo vltimo testamento contenta. DAZd, RB, TS, kut. 3, sv. XI, fol. 165r.

96 debere sepeliri in vna sepultura sub ecclesiam sancti Petri de Nadre honorate et honeste secundum suam condictionem et sicut videbitur suis commissariis suprascriptis. DAZd, RB, TS, kut. 3, sv. XI, fol. 165r.

97 Item reliquit ecclesie sancte Marie chatedrali de Arbo ducatos viginti auri et episcopatui Arbensis ducatos viginti pro anima sua et remissione peccatorum suorum. HR DAZd, RB, TS, kut. 3, sv. XI, fol. 165r.

98 ... de his ducatos quadraginta quos dixit debere habere a ser Zedolino de Zudenicho. DAZd, RB, TS, kut. 3, sv. XI, fol. 165r. 
smislu Toma ostaje unutar okvira pobožnosti svoga vremena. Naime, XV. st. je, nastavljajući se na XIV. st., još uvijek dopuštalo vjeru u ostvarenje »svetoga grada« na zemlji jer su dalmatinske komune još uvijek mogle dovoljno izdvajati za izgradnju i obnovu urbanih sakralnih i milosrdnih objekata. No, od XVI. st., ponajprije zbog osmanske opasnosti, pobožnost usmjerena prema »svetom gradu« jest napuštena, ponajprije zbog općega osiromašenja pripadnika sviju staleža.

Jedan od njegovih dužnika, rapski patricij Damjan de Hermolais stariji (senior), na ime duga prema Tomi trebao je dati crkvi sv. Katarine na Komrčaru 25 zlatnih dukata za neke radove koji su se trebali izvršiti na njoj. ${ }^{99}$ Ostatak Damjanova duga Toma je darovao u dobrotvorne svrhe. ${ }^{100}$ Nadalje je, od novca koji su mu dugovali neki pojedinci, svakom rapskom kanoniku darovao je po jedan zlatni dukat, svakom mansionaru odnosno kanoniku sa stalnom rezidencijom u Rapskom kaptolu pola dukata, a svakom đakonu i podđakonu rapske crkve 20 malih solida za odrješenje njegovih grijeha te uz uvjet da mole za njegovu dušu. ${ }^{101}$

Oporučni legati koje je Toma distribuirao u novcu kazuju da je ovaj rapski svećenik bio financijski dobro situiran, a njegov financijski položaj bio je podjednako posljedica razgranata poslovanja s pripadnicima rapskoga društva, podjednako patricijima i građanima kao i stanovnicima rapskoga distrikta, ali i pojedincima iz drugih gradova. Kako saznajemo iz ostatka oporuke, Toma je posjedovao priličan broj nepokretnih dobara (više kuća i zemljišta na Rabu) te velik broj krupne i sitne stoke (krava i ovaca) u zajednici s različitim pojedincima rapskoga društva, samim izvršiteljima njegove oporuke, biskupom Ivanom iz rapske patricijske obitelji de Scaffa i bilježnikom Andrijom Fajetom, zatim s Marinom iz rapske patricijske obitelji Nimira, ${ }^{102}$ kao i pojedincima s područja rapske komune, Marinom de Sfaina i Jako-

99 Item dixit debere habere certos ducatos a nobili viro ser Damiano de Hermolao senioris quorum dimisit ecclesie sue sancte Catharine ducatos vigintiquinque auri pro aliqua fabrica necessaria ibidem fienda pro anima sua. DAZd, RB, TS, kut. 3, sv. XI, fol. 165r.

${ }^{100}$ Et totum residuum quid dixit debere habere a dicto ser Damiano ... reliquit pro bono amore. DAZd, RB, TS, kut. 3, sv. XI, fol. 165r.

101 ... cuilibet canonico Arbensi ducatum vnum auri et cuilibet mansionarie medium ducati et cuilibet diacono et subdiacono ecclesie Arbensis solidos viginti paruorum pro anima sua et pro remissione suorum peccatorum vt orent Deum pro eo. DAZd, RB, TS, kut. 3, sv. XI, fol. 165r.

${ }^{102}$ U oporuci se, naime, navodi da notaru koji je zapisao oporuku, tj. Tomi Stančiću, ostavlja dio svojih životinja koje ima u zajedništvu s biskupom Ivanom de Scaffa i Marinom de Nimira na pasištu na lokalitetu Muchia kao i jedan svoj ogrtač od crne tkanine. (Item reliquit mei notario infrascripto partem suarum animalium quas habet in sotietate cum reuerendo domino episcopo suprascripto et cum Marino de Nemira in pascoa dela Muchia et vnum suum mantellum de panno nigrum pro bono amore vt orem Deum pro anima sua. DAZd, RB, TS, kut. 3, sv. XI, fol. 165r-165v.) Po svemu sudeći, navedeno je pasište na lokalitetu Muchia Toma posjedovao upravo zajedno s pripadnicima rapske crkvene elite, samim biskupom Ivanom de Scaffa i patricijem Marinom de Nimira, uglednim Rabljaninu te pripadnikom obitelji koja je u sljedećoj generaciji iznjedrila uglednoga humanističkoga pisca Martina Nimiru (Martinus Nimireus, 
vom Paulićem iz Kampora. Svakome od tih pojedinaca namijenio je u ostavštini dio stoke koju je posjedovao samostalno ili u zajednici s njima. ${ }^{103}$

Zemljišta je posjedovao na području rapske komune, na lokalitetima Drendoli ${ }^{104} \mathrm{i}$ Kampor. Spomenuo je ujedno i više kuća u svojemu vlasništvu, ali bez naznake lokacije.

Među bliskim osobama koje spominje kao primatelje svoje ostavštine jesu nećakinja mu Menci i nećak Ivan, te kao univerzalni nasljednici, koji su obično bili najbliži rod samoga oporučitelja, sestra Antonina i, kako se doslovno navodi u samoj oporuci, njezin nećak Ivan, sin Tomine služavke Katarine. No, pritom je riječ upravo o Tominu i Katarininom sinu, kojega je, kako saznajemo iz dokumenta iz 1472., palatinski grof Andrija de Dominis ozakonio posebnom ispravom. ${ }^{105}$ Upravo je, naime, njemu Toma namijenio velik dio svoje ostavštine, više kuća koje su se nalazile na području rapske komune (kao što je rečeno nije precizno rečeno gdje su locirane), a koje bi, u slučaju da Ivan ne doživi punoljetnost tj. 14. godina (aetas legitima) te umre bez oporuke i bez nasljednika, trebalo dodijeliti rapskim franjevkama trećoretkinjama (picokarama) za stanovanje ili za potrebe uređenja hospitala za zbrinjavanje siromašnih. ${ }^{106}$ Ovaj legat upućuje na Tominu milosrdnu i karitativnu osjetljivost i naklonost prema laičkim redovnicama picokarama koje su obično skrbile o siromašnim i marginaliziranim članovima komunalnih sredina, a time i njegova trajna karitativna uloga u rapskoj zajednici. Ne iznenađuje to imamo li na umu da je Toma u trenutku sastavljanja oporuke bio prior crkve sv. Katarine na Komrčaru, koja se nalazila u neposrednoj blizini samostana franjevaca trećoredaca i lazareta sv. Katarine. Ovim se legatom Toma uklapa u opći trend kasnosrednjovjekovnoga »socijalnoga i civilnoga kršćanstva«, a čija je osnovna karakteristika bila izražena u riječima caritas et misericordia prema osobama koje su, iz raznih razloga, živjele neprimjetno i siromašno na rubovima komunalnih društava.

M. Nimireus), kojega spominje i Odorik Badurina (Velika kamporska kronika, Liber II, str. 56). Više o Martinu Nimiri vidjeti u tekstu Gorane Stepanić: Nimira, Martin, Leksikon hrvatskih pisaca. Zagreb, Školska knjiga 2000., str. 533.

${ }^{103}$ DAZd, RB, TS, kut. 3, sv. XI, fol. 165r-165v.

${ }^{104}$ Ibid.; Riječ je o u izvorima često spominjanom, ali u literaturi nedefiniranom toponimu na Rabu. O tumačenju toga toponima vidjeti primjerice: Valentin Putanec: Diferencijacija konzonanata tipa n > nd u hrvatsko-srpskom jeziku. Filologija, 6, 1970., str. 145.

105 I. Pederin: Svakidašnjica u Rabu, str. 17, 28.

106 In ceteris autem suis bonis mobilibus et immobilibus presentis et futuris in presenti testamento inordinatis vndique sibi spectantibus et pertinentiis instituit suos heredes vniuersales dominam Anthoninam, sororem suam, ad gubernandum et gaudendum bona sua in vita sua tamen et Iohannem, nepotem dicte domine Anthonine, videlicet filium Catherine alias seruicialie sue. Ita et tali modo quod si dictus Iohannes heres suus decesserit ante perfecta etatem absque testamento uel etiam absque heredibus legittimis voluit et ordinauit domos totas sue habitationis dentur pro habitatione piçocharis mulieribus Tercii ordinis sancti Francisci de Arbo uel quod in eis fieret vnum hospitale pro habitatione pauperes Christi prout videbitur melius et honestius suis commissariis suprascriptis pro anima sua. DAZd, RB, TS, kut. 3, sv. XI, fol. 165v. 
U završnom dijelu Tomine oporuke, u kojem raspoređuje glavninu imovine univerzalnim nasljednicima, stoji i odredba prema kojoj u slučaju Ivanove smrti prije nego što postigne punoljetnost polovica preostalih dobra (znači, uz kuće koje su se trebale upotrijebiti za navedenu svrhu) ima pripasti njegovoj sestri Antonini i njezinim nasljednicima, a polovica se treba prodati i dobiveni novac razdijeliti rapskim crkvenim ustanova i siromašnima ${ }^{107} \mathrm{U}$ zadnjoj rečenici oporuke naglašava i to da crkvi sv. Nikole de Sarigno ostavlja tri povezana komada oranica na području Kampora. ${ }^{108}$

U posljednjoj Tominoj sačuvanoj oporuci, onoj iz $1478,{ }^{109} \mathrm{u}$ kojoj se spominje kao venerabilis dominus Thomas de Zanzarellis canonicus arb. et prior loci prioratus $s$. Cat. de Chamenzario, a koja je napisana u njegovoj poodmakloj dobi, ponovno se spominju darivanja pojedinim sakralnim i karitativnim ustanovama, kao i njegova želja da njegov nasljednik (ili netko umjesto njega) pođe, u njegovo ime, na hodočašća u Rim, Assisi, Recanati i Jeruzalem, za što je ostavio 50 dukata. Među ostalim, ostavlja neka svoja dobra pustinjacima i redovnicima priorata sv. Katarine, a samom lazaretu 1 zlatni dukat.

Vidno je da i u ovoj posljednjoj svojoj oporuci, kao i u prethodne dvije, veliku važnost Toma daje hodočašćima kao vjerskom izričaju te daruje rapske vjerske i karitativne ustanove, prvenstveno lazaret, crkvu i redovnike priorata sv. Katarine na Komrčaru prior kojega je tada bio već gotovo četiri desetljeća.

\section{Analiza natuknica u Hrvatskom biografskom leksikonu (HBL)}

Namjera je analize koja slijedi utvrditi po kojem bi kriteriju dvojica uglednih pojedinaca, koji su zabilježeni u rapskim izvorima druge polovice XV. st., mogli biti uvršteni u Hrvatski biografski leksikon (HBL). Sagledano je pritom pet kategorija dosadašnjih ulaznika u tu ediciju, bilo da je riječ o već obrađenim člancima, koji su objavljeni u nekoj od knjiga, ili onima zastupljenima u integralnoj verziji abecedarija HBL-a koja je djelatnicima Leksikografskoga zavoda Miroslav Krleža dostupna u bazi Osobnik on-line. ${ }^{110} \mathrm{U}$ samoj analizi prvu kategoriju čine pojedinci vezani rođenjem ili djelatnošću za otok Rab u rasponu od XIII. do XVIII. st., ${ }^{111}$ drugu kategoriju čine istak-

${ }^{107}$... pro anima sua ecclesiis uel pauperibus Christi... i to kako odrede izvršitelji oporuke. DAZd, RB, TS, kut. 3, sv. XI, fol. 165v.

108 Item reliquit ecclesie sancti Nicolai de Sarigno tres petias terre aratorias simul conexas, positas in Campora pro anima sua et remissione peccatorum suorum. DAZd, RB, TS, kut. 3, sv. XI, fol. $165 \mathrm{v}$.

109 Odorik Badurina: Velika kamporska kronika. Liber II, str. 34.

110 Podatci u bazi Osobnik on-line podložni su stalnim dopunama i izmjenama, sama baza oblikovana je unutar redakcije Thesaurus u Leksikografskom zavodu Miroslav Krleža (gl. urednica Nataša Bašić).

111 Premda je ovaj rad posvećen biografiji dvaju pojedinaca, predstavnika rapske društvene elite iz XV. st., sama analiza korpusa natuknica Hrvatskoga biografskoga leksikona izrađena je za prostor rap- 
nute rapske obitelji koje su obilježile povijest Raba, treću kategoriju čine bilježnici odnosno notari, četvrtu kategoriju dobrotvori, a petu kulturni djelatnici koji su djelovali od XIII. do XVIII. st.

Pogledamo li prvu kategoriju ulaznika, uočit ćemo dominaciju pojedinaca pripadnika uglednih plemićkih rapskih obitelji, pojedince pripadnike hrvatskoga plemstva koji su dio života proveli na Rabu, ali i pojedince koji su predstavnici visoke crkvene hijerarhije, posebice rapski biskupi, bilo da su podrijetlom iz Raba ili iz nekoga drugoga kraja. Što se tiče rapskih obitelji, u navedenom razdoblju mahom su izdvojene i obrađene ili se tek planiraju obraditi plemićke obitelji (Bizza, Crnota, Dominis, Galzigna, Hermolais, Spalatin), dok pučka obitelj nije obrađena niti se planira objaviti niti jedna. Vjerojatno se radi o obiteljima koje su uvrštene u abecedarij, zahvaljujući dobroj obrađenosti u znanstvenoj literaturi kao i dostupnosti objelodanjenih vrela, dio plemićkih obitelji kakvih je u razdoblju od XIII. do XVIII. st. bio veći broj na Rabu vjerojatno nije obrađen niti planiran za uvrštenje zbog slabije zastupljenosti u znanstvenoj literaturi. Istaknimo na ovom mjestu, primjerice, obitelj de Zaro (Car), ${ }^{112}$ koja je imala istaknutu ulogu u životu rapske komune te dala više istaknutih pojedinaca, primjerice bogatoga plemića Petra de Zaro, dobrotvora gradskoga hospitala, patrona samostana sv. Bernardina Sijenskoga u Kamporu na Rabu te donatora više crkvenih i karitativnih ustanova. ${ }^{113}$ Natuknica o njemu nije planirana kao zasebni članak, jednako kao niti natuknica o obitelji iz koje potječe. Spomenimo samo usput da u okvirima HBL-a postoji jedna osoba istoga imena - Car, Petar s nadimkom Zvrk, društveno-politički radnik koji je živio u XX. st., a bio je, među ostalim, organizacioni politički sekretar OK KPH za Osijek i organizacioni sekretar GK KPH za Zagreb. ${ }^{114}$

Među natuknicama pojedinaca vezanih uz povijest Raba nije istaknut niti jedan javni bilježnik odnosno notar. Napomenimo da se unutar HBL-a, bez ikakva historiografskoga i općenito znanstvenoga razloga, razlikuju ta dva pojma te je izraz bilježnik više vezan uz gradske ili komunalne bilježnike koji su se koristili latinicom i latinskim jezikom, a izraz notar za pojedince koji su se koristili glagoljicom u bilježenju javnih ili nekih drugih, primjerice crkvenih isprava. Iako, što se tiče Raba i rapske povijesti, u okvirima HBL-a nije izdvojen niti jedan notar odnosno bilježnik unutar zasebnoga članka, pojedini od njih spominju se unutar članaka o obiteljima.

ske komune u rasponu XIII-XVIII. st., koje se može smatrati određenom kulturološkom cjelinom, iz razloga što bi razmatranje uskoga vremenskoga perioda koje se vezuje uz renesansu (XV-XVI. st.) dalo premali uzorak obiteljskih i osobnih imena potrebnih za analizu.

112 D. Mlacović: Građani plemići, str. 243; M. Kunčić: Dalmatinski patricijat i socijalno kršćanstvo, str. 25-76, osobito str. 51-55.

113 Ibid.

114 Darko Stuparić: Car, Petar-Zvrk. Hrvatski biografski leksikon, 2. Zagreb 1989., str. 580. 
Česti su, primjerice, spomeni notara iz rapskim obiteljima Crnota (Černota) ${ }^{115}$ i Hermolais. ${ }^{116}$ Kada su u pitanju notari koji su se koristili glagoljicom u bilježenju javnih isprava, $u$ izvornom je abecedariju HBL-a bila planirana izrada natuknice o rapskom notaru Marinčulu (Marinu) Maromanu, koji je živio i djelovao u drugoj polovici XV. st. Na koncu taj pojedinac ipak nije uvršten u knjigu, vjerojatno iz razloga što o njemu u znanstvenoj literaturi nije bilo dovoljno podataka da bi se napisao zaseban članak, iako izvorni podatci donose niz zanimljivosti vezanih uz njegovu djelatnost. ${ }^{117}$ Gledano u cjelini, u cjelokupnom korpusu HBL-a glagoljski su notari kao samostalne natuknice zastupljeni u većoj mjeri nego bilježnici koji su pisali latinskim jezikom te latinicom. To bi se moglo s jedne strane objasniti dobrom obrađenosti glagoljskih notara u starijoj znanstvenoj literaturi (kakva je dominirala u vrijeme sastavljanja temeljnoga abecedarija HBL-a), a koja je proizišla iz njihove važnosti za razvoj hrvatskoga jezika u cjelini. Rjeđe su, kao što je već istaknuto, izdvojeni u zasebnim člancima pojedini komunalni bilježnici koji su bilježničke knjige zapisivali latinicom i latinskim jezikom, i to samo ako su se uz svoju temeljnu djelatnost istaknuli i nekom drugom djelatnošću, ili ako su jednostavno bili bolje obrađeni u literaturi. Uglavnom se to odnosi na istaknutije komunalne bilježnike u Zadru, Splitu, Šibeniku i Dubrovniku (primjerice Franjo iz Bolonje, ${ }^{118}$ koji je u XIV. st. djelovao u Splitu, ili Creste de Tarallo, ${ }^{119}$ koji je djelovao u XIII. st. u Zadru). Jedan od razloga slaboj zastupljenosti latinskih bilježnika unutar HBL-a vjerojatno leži u činjenici što je proučavanje bilježništva u gradovima i komunama u hrvatskoj historiografiji u vrijeme oblikovanja glavnine abecedarija bilo tek u začetcima. Općenito uzevši, gradski bilježnici nisu unutar HBL-a obrađeni sustavno za sve gradske sredine, što se u konačnici može objasniti i njihovom brojnošću i naravi posla koja je podlijegala pravilima gradskih i komunalnih statuta te je bila prilično ustaljena.

Jednako kao niti bilježnik ili notar, niti jedan pojedinac s prostora rapske komune nije istaknut u zasebnom članku kao dobrotvor. Sagleda li se cjelokupan korpus natuknica HBL-a, takva je odrednica nerijetko zastupljena u svim dosad objavljenim knjigama, kao i u ostatku abecedarija ovoga izdanja. Podjednako je ta odrednica dodijeljena osobama iz starije povijesti (do XVIII. st.), kao i onima iz novije povijesti, podjednako pripadnicima plemstva kao i pučanima, često duhovnim osobama. Pri-

115 Tatjana Radauš: Crnota, plemićka obitelj na Rabu. Hrvatski biografski leksikon, 2. Zagreb 1989., str. $746-747$.

116 Pejo Ćošković: Hermolais, rapska plemićka obitelj. Hrvatski biografski leksikon, sv. 5. Zagreb 2002., str. 558-560.

117 Vidjeti bilj. 19.

118 Serđo Dokoza Nikpalj: Franjo iz Bolonje. Hrvatski biografski leksikon, sv. 4. Zagreb 1998., str. $445-446$.

119 Ivan Pederin: Creste de Tarallo. Hrvatski biografski leksikon, sv. 2. Zagreb 1989., str. 714-715. 
padnici pojedinih obitelji, kao što je to slučaj s obitelji Erdődy, ${ }^{120}$ osobito su često istaknuti tom odrednicom, no kategorija dobrotvornosti protkana je kroz sve članke gdje se smatralo da je ona važna spomena.

Za prostor rapske komune u okvirima HBL-a nema niti jednoga pojedinca koji bi bio istaknut kao kulturni djelatnik. Treba istaknuti da je odrednica kulturni djelatnik primijenjena na veći broj pojedinaca različitih zanimanja koji su imali istaknutu ulogu u kulturnom životu pojedinih sredina, ali je zamjetno da su unutar te kategorije uglavnom zastupljene osobe koje su djelovale nakon XVIII. st. No, postoji i priličan broj primjera kada je ta odrednica primijenjena na pojedince koji su djelovali u ranijim vremenskim razdobljima, pa tako i razdoblju kasnoga srednjega vijeka. Navedimo samo kao primjer zadarskoga trgovca i kulturnoga djelatnika Grgura Mrganića (o. 1390-1460), ${ }^{121}$ darovatelja više crkvenih i karitativnih ustanova na području zadarske komune. Treba istaknuti i činjenicu da je kulturna djelatnost pojedinaca u okvirima cijele edicije naglašena kao važna komponenta nečije djelatnosti i redovito je zastupljena gdje god se smatralo da je vrijedna spomena. Primjećujemo to, uostalom, i kada je riječ o pojedincima koji su djelovali na području Raba u navedenom razdoblju, bilo da je riječ o člancima o pojedincima ili o obiteljima.

\section{Zaključak}

Analiza rapskoga arhivskog gradiva općenito upućuje na nedostatnu obrađenost unutar HBL-a pojedinaca i obitelji vezanih uz povijest rapske komune od XIII. do XVIII. st., što je zasigurno uzrokovano nedostatnom istraženošću rapske povijesti od strane znanstvenika u razdoblju od 1980-ih do 2010-ih kada se formirala glavnina abecedarija toga izdanja. Zahvaljujući većem broju historiografskih studija objelodanjenih u posljednjem desetljeću napravljen je velik pomak u proučavanju toga segmenta rapske povijesti. Zadaća je suvremene generacije leksikografa registrirati ta novija istraživanja, jednako za prostor Raba kao i niz drugih urbanih sredina te unijeti niz dopuna i prijedloga kojima bi se upotpunila slika o djelovanju obitelji i pojedinaca važnih za pojedine sredine. U slučaju Raba, pojedine istaknute obitelji mogle bi se, primjerice, unijeti kao novi prijedlozi s obzirom na razinu dosadašnje istraženosti u znanstvenoj literaturi te na opseg arhivskoga gradiva. Vrela i literatura pokazuju da bi se mogli unijeti i neki pojedinci, zanimljivi zbog svoje gospodarske, kulturne i dobrotvorne djelatnosti (npr. Petar de Zaro). Što se tiče dvaju ovdje razmatranih rapskih kanonika, postavlja se pitanje kakve su njihove šanse da postanu dije-

120 Tatjana Radauš: Erdődy, velikaška obitelj. Hrvatski biografski leksikon, sv. 4. Zagreb 1998., str. $54-65$.

${ }^{121}$ Riječ je o tekstu koji još uvijek nije objavljen, a dotična je odrednica (kulturni djelatnik) unesena u bazu Osobnik on-line koja je, kao što je već naznačeno, podložna izmjenama. 
lom HBL-a. Na temelju provedene analize pet kategorija natuknica unutar kojih bi se mogli obraditi, čini se da razloga njihovu uvrštenju najviše daje njihova vrlo aktivna sakralna djelatnost, zatim pripadnost kulturnom krugu koji je uvelike utjecao na kreiranje renesansnoga Raba druge polovice XV. st., te njihova karitativna djelatnost unutar koje se ističe skrb o rapskim karitativnim i crkvenim ustanovama.

Primijetimo na ovom mjestu nekoliko zanimljivih podudarnosti. Upravo u vrijeme dok je notar Toma Stančić bio prior oltara Tijela Kristova u katedralnoj crkvi sv. Marije potpisano je u njegovoj notarskoj kancelariji više ugovora s majstorom Andrijom Alešijem kojima se dogovaralo uređenje prostora oko oltara odnosno izrada kamenih ogradica s kipovima anđela za taj isti oltar (ugovor iz 1456). ${ }^{122}$ Jednako je tako Toma kao notar svjedočio i sastavljanju raznih drugih ugovora kojima su se uređivali sakralni prostori kasnosrednjovjekovnoga Raba. ${ }^{123}$ Nesumnjivo je trenutak sastavljanja jednog takvog ugovora bio osjetljivo mjesto na kojem su različite stranke iskazivale svoja htijenja i financijske mogućnosti, a Toma je kao poznavatelj s jedne strane crkvenih i svjetovnih pravnih propisa te napose izvrstan poznavatelj vjerskih temelja različitih vidova pobožnosti koji su u njegovo doba prožimali rapsko društvo, bio jedan od ključnih sudionika takva događaja kojem je na određeni način mogao dati usmjerenje i zaključni oblik. Na temelju takvih ugovora, međutim, koji ipak, kao i u većini ostalih istočnojadranskih komuna, zadržavaju ujednačenu formu te samo u ponekom detalju iskazuju htijenje naručitelja, u smislu nekoga ikonografskog i stilskoga rješenja, teško je govoriti u kategorijama naručiteljeva snažnijega utjecaja na krajnji ishod umjetničko-zanatskoga djela. No, ono što se može sagledati šire je kulturološko ozračje unutar kojega su takvi ugovori nastajali, a koji su upravo Toma Stančić, kanonik i notar, ali i Toma Zangarel, kanonik i prior crkve sv. Katarine na Komrčaru bili kreatori, u kasnom srednjovjekovlju na prostoru rapske komune. Riječ je, naime, o pojedincima koji su dijelili zajedničku vjersku kulturu sredine kojoj su pripadali. A bilo je to vrijeme preuzimanja vjerskih ideja koje su strujale s europskoga zapada u vidu pobožnosti Tijela Kristova i uvažavanja laičkih redova sklonih njegovanju karitativne djelatnosti. S takvim idejama, koje su izražavane često kroz različite vidove umjetničkoga stvaranja (uvođenje svetkovine Tijela Kristova utjecala je izrazito na razvoj crkvene glazbe), dolazili su i određeni stilski utjecaji. Posebice kada je riječ o Tomi Zangarelu kanoniku i prioru crkve sv. Katarine na Komrčaru, može se ustvrditi da je njegovo osobno financijsko bogatstvo, stečeno vjerojatno zahvaljujući dijelom nasljedstvu, a dijelom vlastitoj poslovnoj poduzetnosti, uz istaknut položaj unutar rapske svećeničke hijerarhije, omogućilo pokretliivost i povezanost s različitim slojevima rapskoga društva te društava ostalih komuna na Jadranu. S lakoćom je taj okretan poduzetnik i trgovac, vješt poznavatelj prava i pregovarač, obrazovani sveće-

\footnotetext{
${ }^{122}$ Vidjeti bilj. 40.

${ }^{123}$ Ibid.
} 
nik s poznavanjem crkvenih kanona i suvremenih mu vjerskih trendova, ulazio u pregovore s predstavnicima društvene elite, trgovcima i majstorima koji su opremali sakralne i karitativne ustanove kojih je on sam bio upravitelj i prior. Imajući sve to na umu, razložno je pretpostaviti da su upravo oba rapska kanonika s imenom Toma pripadala skupini Rabljana koji su pozivali i odabirali tada ugledne gotičko-renesansne majstore kako bi ukrasili i dogradili rapske stambene i sakralne prostore, a ugovore s mnogima od njih zabilježio je upravo jedan od njih u svojoj notarskoj kancelariji.

\section{NEOBJAVLJENI IZVORI}

Arhiv samostana sv. Frane u Zadru, Zbirka isprava na pergameni, isprave br. 95-120, kut. XIV.

Badurina, Odorik, Velika kamporska kronika. Liber I-II, Arhiv franjevačkog samostana sv. Bernardina Sijenskog (sv. Eufemije) u Kamporu na Rabu

Državni arhiv u Zadru, Rapski bilježnici, Toma Stančić (Thomas de Stanciis), kut. 2, sv. IV, VI-VIII, X-XI; kut. 3, sv. XX.

Državni arhiv u Zadru, Rapski bilježnici, Andrija Fajeta (Andreas de Faeta), 1458-1477., kut. 1, sv. IV-X. ACA (Archiv. Capituli Arbi), Arhiv bivšega Rapskoga kaptola, Legata Ecclesiae Cathedralis, Liber 26. ACA (Archiv. Capituli Arbi), Arhiv bivšega Rapskoga kaptola, Documenta dioc. Arbensis, Liber 43.

\section{IZVORI I LITERATURA}

Antoljak, Stjepan (1986). Izvori i literatura o prošlosti otoka Raba od ranog srednjeg vijeka do godine 1797. Filozofski fakultet Zadar/Skupština općine Rab, Zadar-Rab.

Beg, Natalia (2019). Rapska obitelj Dokulo: o heraldičkom znaku, njihovoj vezi s otokom Krkom i obnovom kapele pokraj rapske katedrale. Krčki zbornik, 75, str. 17-36.

Benyovsky Latin, Irena (2010). Razvoj srednjovjekovne operarije - institucije za izgradnju katedrale u Trogiru. Croatica Christiana periodica, 34/65, str. 1-18.

Bratulić, Josip (2017). Hrvatske glagoljične i ćirilične isprave iz zbirke Stjepana Ivšića 1100.-1527., Acta Croatica. Hrvatski spomenici, knj. 1., HAZU, Zagreb.

Braut, Ivan, Majer Jurišić, Krasanka, Šurina, Edita (2020). Franjevački samostanski kompleks sv. Bernardina Sijenskog u Kamporu na otoku Rabu. Mala biblioteka Godišnjaka zaštite spomenika kulture Hrvatske, 21. Zagreb.

Brusić, Vladislav (1926). Otok Rab: geografski, historijski i umjetnički pregled sa ilustracijama i geografskom kartom Kvarnera i Gornjeg Primorja. Franjevački kamporski samostan sv. Eufemije, Rab.

Ćošković, Pejo (2002). Hermolais, rapska plemićka obitelj. Hrvatski biografski leksikon, sv. 5. Zagreb, str. $558-560$.

Domijan, Miljenko (2001). Rab. Grad umjetnosti. Barbat, Zagreb.

Dokoza Nikpalj, Serđo (1998). Franjo iz Bolonje. Hrvatski biografski leksikon, sv. 4. Zagreb, str. 445-446.

Farlati, Daniele (1775). Illyricum sacrum, 5. Venetiis, apud Sebastianum Coleti.

Fisković, Cvito, Prijatelj, Kruno (1948). Albanski umjetnik Andrija Aleši u Splitu i Rabu. Izdanje Konzervatorskog zavoda za Dalmaciju u Splitu, Split.

Fisković, Cvito (1974). Iz glazbene prošlosti Dalmacije. Mogućnosti, 21/6-7, str. 711-764. 
Granić, Miroslav (1980-81). Privilegij cara Sigismunda rapskoj obitelji Dominis iz godine 1437. Radovi Filozofskog fakulteta u Zadru, 20/9, str. 53-62.

Grmek, Mirko Dražen (1949). Povijest zdravstva na Rabu. Medicinar, 3/6, str. 291-302.

Gulin, Ante (2008). Hrvatski srednjovjekovni kaptoli - Loca credibilia Dalmacije, Hrvatskog primorja, Kvarnerskih otoka i Istre. HAZU, Zagreb.

Konestra, Ana, Welc, Fabian, Androić Gračanin, Paula, Rabiega, Kamil, Nowacki, Bartosz, Kukela, Agnese (2020). Tipologija i organizacija otočnih naselja Raba kroz dijakronijski pristup Prvi podaci multidisciplinarnih istraživanja. Godišnjak Instituta za arheologiju, 16, str. 229-244.

Kudiš Burić, Nina (2008). Oltari presvetog Sakramenta u Savičenti i Osoru: problemi konteksta, tipologije, uzora i autora. U: Renesansa i renesanse u umjetnosti Hrvatske: zbornik radova sa znanstvenih skupova »Dani Cvita Fiskovića« održanih 2003. i 2004. godine (ur. Predrag Marković, Jasenka Gudelj), Institut za povijest umjetnosti u Zagrebu-Odsjek za povijest umjetnosti Filozofskog fakulteta Sveučilišta, Zagreb, str. 297-312.

Kunčić, Meri (2016). Dalmatinski patricijat i socijalno kršćanstvo. O srednjovjekovnim rapskim hospitalima s posebnim osvrtom na hospital Tijela Kristova i njegova utemeljitelja Petra de Zaro. Croatica Christiana periodica, 4/77, str. 25-76.

Kunčić, Meri, Ladić, Zoran (2003). Rabljani u tisućugodišnjem okrilju svetoga Kristofora. Hrvatska revija, 3/2, str. 85-89.

Ladić, Zoran (2018). O šibenskim hospitalima i leprozorijima kasnog srednjeg vijeka prema bilježničkim spisima. U: Šibenik od prvog spomena (ur. Iva Kurelac). Muzej grada Šibenika, Šibenik, str. 153-174.

Leksikon ikonografije, liturgike i simbolike zapadnog kršćanstva (ur. Anđelko Badurina) (1979). Sveučilišna naklada Liber-Kršćanska sadašnjost-Institut za povijest umjetnosti, Zagreb.

Leljak, Robert (1994). Sumarni Inventar. Rapski bilježnici 1403-1875, br. fonda: HR DAZD 28. Državni arhiv u Zadru, Zadar.

Lonza, Nella (2010). Dubrovački studenti prava u kasnom srednjem vijeku. Anali Zavoda za povijesne znanosti HAZU u Dubrovniku, 48, str. 9-45.

Margetić, Lujo (2004). Iz starije pravne povijesti Raba, u: Lujo Margetić i Petar Strčić, Statut rapske komune iz 14. stoljeća. Grad Rab /Adamić/, Rab-Rijeka, str. 21-75.

Mlacović, Dušan (1994). Slika svete Katarine. Otium, 4/1-2, str. 31-34.

Mlacović, Dušan (2005). Supetarska Draga na Rabu v srednjem veku, Raukarov zbornik, Zbornik u čast Tomislava Raukara (ur. Neven Budak). Filozofski fakultet Sveučilišta u Zagrebu-Odsjek za povijest, Zagreb 2005, str. 513-535.

Mlacović, Dušan (2008). Građani plemicii: pad i uspon rapskog plemstva. Leykam international, Zagreb.

Montani, Miroslav (1965). O radovima Jurja Dalmatinca i njegova kruga. Ljetopis $\mathcal{F A Z U , ~ 7 0 , ~ s t r . ~}$ $455-481$.

Ostojić, Ivan (1975). Stara bratovština presv. Tijela Kristova u Splitu - prvi dio. Bogoslovska smotra, 45/4, str. 479-488.

Pederin, Ivan (1982). Fond rapskih knezova i bilježnika. Vjesnik Historijskih arhiva u Rijeci i Pazinu, 25, str. 9-43.

Pederin, Ivan (1989). Creste de Tarallo. Hrvatski biografski leksikon, 2. Zagreb, str. 714-715.

Pederin, Ivan (1989). Commercio, economia, pesca, arti e mestieri in Arbe nel Quattrocento. Archivio storico italiano (Firenze), 147, str. 215-249.

Pederin, Ivan (1994). Uprava, crkva, politika i kultura na Rabu u XVI. stoljeću. Radovi Zavoda za povijesne znanosti HAZU u Zadru, 36, str. 125-180.

Pederin, Ivan (1994). Glazba na renesansnom Rabu. Arba: revija za Rabljane i njihove goste, 1, str. 27-28. 
Pederin, Ivan (2011). Svakidašnjica u Rabu: od mistike do renesanse i baroka. Matica hrvatska, Rab.

Potočnjak, Saša (2019). »Facta est«. Frammenti apocrifi del Nuovo Testamento dall'isola di Arbe. U: La Serenissima via mare - Arte e cultura tra Venezia e il Quarnaro (ur. Valentina Baradel, Cristina Guarnieri). Padova University Press, str. 87-98.

Praga, Giuseppe (2014). La traslazione di S. Niccolò e i primordi delle guere normanne nell'Adriatico. U: Scritti sulla Dalmazia, 2. Rovigno-Fiume-Trieste, str. 97-267.

Putanec, Valentin (1970). Diferencijacija konzonanata tipa n $>$ nd u hrvatsko-srpskom jeziku. Filologija, 6, str. 139-153.

Radauš, Tatjana (1989). Crnota, plemićka obitelj na Rabu. Hrvatski biografski leksikon, 2. Zagreb, str. $746-747$.

Radauš, Tatjana (1998). Erdődy, velikaška obitelj. Hrvatski biografski leksikon, sv. 4. Zagreb, str. 54-65.

Runje, Petar (1987). Franjevci trećoreci-glagoljaši na Rabu u srednjem vijeku. U: Rapski zbornik I (ur. Andre Mohorovičić). JAZU - Skupština općine Rab, 1987, str. 333-336.

Runje, Petar (1999). Glagoljaši javni bilježnici. Senjski zbornik, 26, str. 115-122.

Schleyer, Wilhelm: Arbe. Stadt und Insel, ein Schatzkästlein der Natur und Kunst in Dalmatien. Mit 145 Abbildungen. C. W. Kreidel's Verlag, Wiesbaden 1914.

Stepanić, Gorana, Nimira, Martin (2000). Leksikon hrvatskih pisaca. Školska knjiga, Zagreb, str. 533.

Stipčević, Aleksandar (2004). Socijalna povijest knjige u Hrvata: knjiga 1. Srednji vijek. Školska knjiga, Zagreb.

Stipčević, Ennio (2006). Arhiviranje tišine: kako je pjevala hrvatska Euridika? Kolo, 4, str. 357-380.

Stipčević, Ennio (2015). Iz hrvatske renesanse: o odgoju i glazbi. Croatica et Slavica Iadertina, 11/1, str. 105-117.

Stuparić, Darko (1989). Car, Petar-Zvrk. Hrvatski biografski leksikon, sv. 2. Zagreb, str. 580.

Vidaković, Albe (1963). Tragom naših srednjovjekovnih neumatskih rukopisa. Ljetopis $\mathcal{F A Z U , ~ 6 7 , ~ s t r . ~}$ 364-392.

Vuletić, Nikola (2020). Bilješke iz rapske povijesne toponimije: toponimi bez suvremenih potvrda. Folia onomastica Croatica, 29, str. 237-259. 


\title{
WHO IS IMPORTANT AND WHO IS NOT? ON THE REASONS FOR INCLUDING TWO DISTINGUISHED RENAISSANCE RAB CANONS FROM THE STANČIĆ FAMILY INTO THE INTEGRAL ALPHABETICAL LIST OF ENTRIES OF THE CROATIAN BIOGRAPHICAL DICTIONARY
}

\author{
Meri Kunčić \\ The Miroslav Krleža Institute of Lexicography, Zagreb \\ meri.kuncic@lzmk.hr
}

\begin{abstract}
Using source materials, this paper attempts to explore the lives and work of two identically named protagonists of the social and cultural life of Rab in the second half of the $15^{\text {th }}$ century. Namely, at this time there lived two canons named Toma Stančić in the Rab commune, one of whom was the community notary for many years, while the other was the prior of St Catherine's church in Komrčar. They were undoubtedly close relatives who left a significant trace on the cultural history of the Rab commune at that time, prompting the organisation of certain church and charity institutions on Rab, serving as their priors and procurators. Analysis shows that canon and notary Toma Stančić gave a significant contribution to the religious culture of Rab through his transcription of Historia sancti Christophori Martyris and, along with the Rab patrician Petro de Zaro, as a promoter of the new religious cult of the Body of Christ. His contemporary, Toma Stančić, the long-serving prior of St Catherine's church in Komrčar, was an enterprising and agile person who worked with various strata of Rab society, the procurator of the cathedral church and many small churches on Rab. His preserved testament tells of his family circle, close colleagues, and caring for church and charity institutions on Rab. The second part of the analysis discusses the criteria according to which these two individuals could be included in one of the fundamental editions of the Miroslav Krleža Institute of Lexicography, the Croatian Biographical Dictionary.
\end{abstract}

Keywords: Rab; late middle ages; cultural history; Toma Stančić; Croatian Biographical Dictionary 
